\title{
Luís Saia, um pioneiro na restauração de casas bandeiristas
}

\section{Lia Mayumi}

Arquiteta, doutora pela FAUUSP, arquiteta do DPH - Departamento do Patrimônio Histórico - da Prefeitura de São Paulo, integrante do corpo docente da EMASP - Escola Municipal de Administração Pública de São Paulo, Rua Afonso de Freitas 565 apt. 142, São Paulo, SP, CEP 04006-908, (11) 99125 2051, liamay@uol.com.br

\section{Resumo}

O presente artigo é uma síntese de alguns dos temas centrais da nossa tese de Doutoramento Taipa, canela preta, concreto. Esmiuça os aspectos técnicos envolvidos na obra de restauro da Casa do Bandeirante, a morada bandeirista mais conhecida de São Paulo, situando a obra no contexto dos anos 1950, período em que,a cidade e o estado se projetavam no cenário nacional, e quando se fez presente o mito bandeirista. Luís Saia participou ativamente da construção do mito bandeirista, teorizando-o e conceituando a morada bandeirista. Foi pioneiro no estabelecimento dos critérios de restauração de casas bandeiristas, influenciando gerações de profissionais arquitetos restauradores.

Palavras-chave: restauração arquitetônica, casas bandeiristas, taipa.

\section{ntrodução}

Em vinte e três de novembro de 2011 participei, juntamente com os colegas Paulo Garcez Marins e Ana Lúcia Cerávolo, da mesa-redonda intitulada "Luís Saia: história da cidade e conservação do patrimônio", no âmbito do Colóquio Luís Saia: memória e política, organizado pelo IAU-USP / Fundação Pró-Memória de São Carlos / IPHAN-SP, naquela cidade.

Na ocasião apresentei, de maneira sintética, os temas centrais abordados na minha tese de doutoramento, Taipa, Canela-Preta e Concreto, desenvolvida em torno da problemática dos critérios de intervenção presentes nas restaurações de "casas bandeiristas". Salientei o papel de Luís Saia na definição daqueles critérios, pois foi de fato ele, através de escritos, teorias e teses, mas principalmente obras de restauração de casas bandeiristas, o principal responsável pela definição da imagem moderna dessas casas rurais. Saia resgatou esses exemplares arquitetônicos do seu passado colonial e os re-significou, inserindo-os no contexto urbano de uma civilização industrial, através de uma bem articulada operação de dignificação, que incluía tanto a interpretação histórica como a restauração arquitetônica dessas moradias.

O presente artigo apresenta, portanto, uma síntese dos temas centrais da tese, e, com o auxílio de um exemplo de restauração - o da Casa do Butantã, conhecida também como Casa do Bandeirante-, que foi a primeira das casas bandeiristas da Prefeitura de São Paulo a ser restaurada, busca ilustrar o processo de constituição da "casa bandeirista" tal como nos foi legada por Luís Saia.

\section{As casas: o conjunto e seu valor como patrimônio histórico}

As operações de restauração arquitetônica investigadas na nossa tese referem-se a cinco casas bandeiristas, selecionadas a partir de um elenco de trinta e duas identificadas no estado de São Paulo. As cinco casas localizam-se na cidade de São Paulo, e são de propriedade do poder público municipal: Casa do Butantã, Casa do Caxingui, Sítio da Ressaca, Casa do Tatuapé e Sítio Morrinhos. A restauração e a preservação desses imóveis foram promovidas por iniciativas oficiais - a federal e a municipal -, 
1 Luís Saia, Nuto Sant'Anna, Germano Graeser.

2 ANDRADE, M de. Cartas de Trabalho, correspondência com Rodrigo Melo Franco de Andrade (1936-1945). Brasília: MEC-SPHAN-próMemória, Publicações da SPHAN no.33, 1981. pp. 80-106.

3 "Primeiro Relatório", 16 de outubro de 1937. In: ANDRADE 1981, p. 80

4ANDRADE 1981, p. 69.

5ld. Ibidem, p. 69

6 Id. Ibidem, p. 86 fato que determinou a seleção dos exemplares, já que a tese visava a investigar as motivações, critérios e ações concretas de preservação promovidas por instituições oficiais.

Originalmente sedes de propriedades rurais, e datando dos séculos XVIII e XIX, os imóveis estudados classificam-se como residências rurais típicas paulistas, tendo sido algumas delas "descobertas", identificadas e registradas por Mário de Andrade e seus auxiliares ${ }^{1}$ nas primeiras incursões do escritório paulista do IPHAN pelos arredores da cidade, ainda em 1937. Aquele era o primeiro momento de inventariação do patrimônio histórico e artístico nacional, realizado não sem dificuldades pelos técnicos do recém-criado órgão federal.

São bastante conhecidas as dificuldades materiais de toda ordem que o IPHAN enfrentou no cumprimento de suas atribuições na "fase heróica", mas que foram compensadas pelo alto nível de seu pessoal técnico. 0 órgão organizou-se com sua sede no Rio de Janeiro e alguns escritórios regionais espalhados pelo país que dessem conta da tutela dos monumentos localizados na sua respectiva jurisdição territorial. A equipe de Rodrigo Melo Franco de Andrade, primeiro diretor do IPHAN, constituiu-se de colaboradores do quilate de Lucio Costa, Alcides da Rocha Miranda, Edgar Jacinto da Silva, José de Souza Reis e Ayrton de Carvalho, entre outros; em São Paulo Mário de Andrade, que imediatamente passou a contar com a colaboração de Luís Saia, então "(...) engenheirando dedicado e apaixonado de coisas históricas e coloniais (...)", a quem deu "as incumbências principais". 2

Na escala regional, o primeiro relatório encaminhado a Rodrigo M. F. de Andrade por Mário, Assistente Técnico para a região Sul do país, ilustra bem a primeira impressão deste último sobre a qualidade do patrimônio artístico paulista:

"Não é possivel esperar-se de S. Paulo grande coisa com valor artístico tradicional. As condições históricas e econômicas deste meu Estado, a contínua evasão de Paulistas empreendedores para outras partes do Brasil nos sécs. XVII e XVIII, o vertiginoso progresso ocasionado pelo café, são as causas principais de nossa miséria artística tradicional." ${ }^{\prime 3}$

Ao avaliar a singeleza dos exemplares paulistas Mário tinha em mente a sua comparação com os exemplares suntuosos dos ciclos do açúcar e do ouro:

"Você entenderá comigo que não é possivel entre nós descobrir maravilhas espantosas, do valor das mineiras, baianas, pernambucanas e paraibanas em principal." (Carta a Rodrigo, 23 de maio de 1937). ${ }^{4}$ E propõe, finalmente, selecionar um elenco representativo da arquitetura paulista empregando o critério histórico, em detrimento do estético:

"A orientação paulista tem de se adaptar ao meio: primando a preocupação histórica à estética. Recensear e futuramente tombar o pouco que nos resta seiscentista e setecentista, os monumentos onde se passaram grandes fatos históricos. Sob o ponto de vista estético, mais que a beleza propriamente dita (esta quase não existe) tombar os problemas, as soluções arquitetônicas mais características ou originais. Acha bom assim?" (Carta a Rodrigo, 23 de maio de 1937). ${ }^{5}$

Assim é que, ao lado de exemplares religiosos (igrejas, conventos...) e militares (fortificações...), aparecem arrolados ora como "casa velha", ora como "casa-grande", pertencentes à categoria "arquitetura civil", os exemplares que mais tarde seriam conhecidos como casas bandeiristas. O reconhecimento de nenhum valor artístico das casas fez o IPHAN, naquele momento, desconsiderar o seu tombamento federal:

"Arquitetura civil em São Paulo: a bem dizer, não existe na capital de São Paulo mais nenhum prédio de residência que se considere digno da atenção federal. Um serviço estadual, a meu ver, especioso, poderá tombar alguns prédios desses, porém será mais empecilho que guarda da tradição. Propriedades como a casa velha do Tatuapé (...); a casa velha do Caxingui (...); a casa velha do bairro do Limão (...); a casa velha do Jabaquara (...) estão completamente deformados muitos, outros menos, têm interesse histórico mais estadual que nacional; quase nenhum, ou nenhum interesse artístico. " ("Primeiro Relatório", 16 de outubro de 1937) ${ }^{6}$

Portanto, a primeira atribuição de valor às futuras "casas bandeiristas" deveu-se exclusivamente à sua qualidade de "antigo", o que levou Carlos LEMOS a afirmar sobre as casas, décadas depois, que "a sua 'história' foi terem resistido ao tempo sem 
carregar junto a lembrança de fatos expressivos. Velhas esfinges caipiras sem memória." (LEMOS 1993, p. 22)

7 SAIA, L. "Até os 35 Anos, A Fase Heróica". In: REVISTA CJ. ARQUITETURA n 17 . Rio de Janeiro: FC Editora, 1977. Texto originalmente escrito em 1972. p. 16.

8 Dos escritos de SAIA aos quais tivemos acesso, contamos 12 sobre arquitetura civil; 1 de arquitetura religiosa; 3 de urbanismo; 2 de técnicas construtivas; 2 de crítica de arquitetura; 1 sobre tombamento; 1 sobre arte popular. Não se incluem aqui os textos publicados em Morada Paulista.

9 Notas sobre a arquitetura rural paulista do segundo século". In: revista do sphan $\mathrm{n}^{\circ}$ 8. Rio de Janeiro, 1944. pp 211-75.

A valorização das "casa velhas" enquanto patrimônio histórico e artístico ocorreu a partir dos estudos iniciados por Luís Saia. Quando Mário de Andrade se afasta do IPHAN, Saia passou a dirigir o órgão de São Paulo, de $1939^{7}$ até 1975, quando faleceu. Discípulo e herdeiro intelectual de Mário, Saia deu preferência aos estudos da arquitetura civil em detrimento da arquitetura religiosa (KATINSKY 1988, p. 71), conforme é possível constatar ao exame de sua produção escrita. ${ }^{8}$ Foi sob a sua coordenação técnica que se iniciaram e empreenderam ao longo de trinta e cinco anos as restaurações de grande parte dos monumentos paulistas. Por volta dos anos 1950 um corpo de critérios e de procedimentos técnicos de restauração já estava consolidado através das várias experimentações do IPHAN.
Inicia-se na década de 1950 a série de restaurações que constituíram o objeto de nossa pesquisa. Data de 1954 a primeira intervenção numa casa bandeirista de propriedade da Prefeitura Municipal de São Paulo, ente que conta, atualmente, com um acervo arquitetônico de seis dessas casas, sendo uma delas ruína, e que por esse motivo foi excluída da pesquisa. Nos cinco exemplares considerados, duas restaurações foram orientadas pelo próprio Luís Saia como Diretor do IPHAN em São Paulo. Nos demais exemplares os responsáveis pela restauração foram discípulos de Saia, ou quando não, arquitetos influenciados, em maior ou menor grau, pelas suas teorias, teses, ou ainda pelos critérios de intervenção consolidados por Saia em outras obras de restauração.

Os textos e interpretações de Luís Saia sobre a arquitetura rural paulista e a casa bandeirista, ao mesmo tempo em que serviram como referências teóricas para as restaurações, alimentavam-se dos experimentos práticos realizados nos canteiros de obras de restauração, que por sua vez forneciam a matéria-prima para corroborar as interpretações e teses apresentadas nos escritos.

Não é por acaso que, praticamente, coincidem as datas de restauração da Casa do Padre Inácio (1947) com a da publicação de "Notas sobre a arquitetura rural paulista do segundo século"
(1944) ${ }^{9}$ e depois a restauração da Casa do Butantã (1954) com a publicação de "A casa bandeirista uma interpretação" (1955). Ambos os citados são textos seminais, nos quais se estabeleceram as teses fundamentais de Saia sobre as casas bandeiristas, identificando as constantes arquitetônicas do tipo rural bandeirista e justificando o partido arquitetônico da casa em termos sociológicos, relacionando-o a um período de apogeu da cultura paulista colonial.

Julio Katinsky reconhece em sua tese, Casas Bandeiristas - Nascimento e reconhecimento da arte em São Paulo (KATINSKY 1972), que coube o mérito específico por encontrar e recuperar as casas bandeiristas "em primeiro lugar a Luiz Saia, que restaurou algumas casas e estabeleceu publicamente os primeiros critérios para sua caracterização". De fato, Saia teve a incumbência e o privilégio, como dirigente do escritório do IPHAN em São Paulo, de valorizar o patrimônio histórico paulista. E, nessa condição, foi tão pioneiro da interpretação das casas rurais coloniais quanto da sua caracterização, esta última entendida, aqui, como intervenção arquitetônica empreendida com o propósito de confirmar as teorias interpretativas de Saia sobre aquele tipo arquitetônico.

Saia promoveu a valorização da casa rural paulista, conferindo às moradias bandeiristas uma dignidade moldada através das obras de restauração e de um corpo teórico que fundamentava as origens, a configuração formal e o funcionamento desse tipo arquitetônico. A valorização e a dignificação das casas bandeiristas foi condição essencial para a sua incorporação ao elenco de bens que compunham o patrimônio histórico e artístico nacional.

\section{Tipo e partido arquitetônico. teses de origem}

Em 1944 sai publicado na Revista do PHAN número 8 " Notas sobre a Arquitetura Rural do Segundo Século", artigo de Luís Saia escrito a partir de sua experiência com a investigação e a restauração daqueles edifícios rurais. Na ocasião, sete anos depois de Mario de Andrade ter enviado a Rodrigo Melo Franco de Andrade o primeiro Relatório (1937) sobre o patrimônio paulista , Saia já não se refere às casas rurais como "casas velhas", mas sim, como arquitetura rural caracterizada e conhecida, em número de doze - uma até já restaurada pelo próprio 
10 A casa e a capela do sítio de Santo Antônio restauradas em 1939.

Figura 1: O tipo "puro" Casa do Padre Inácio, restaurada em 1947. Fonte: Fotografia da autora, 2004
IPHAN ${ }^{10}$-, nas quais identificara "constantes" e "variantes" tipológicas que o encorajaram a estabelecer uma tese sobre o apogeu e decadência do tipo arquitetônico bandeirista.

Com base no conhecimento de doze exemplares, Saia elabora a caracterização pioneira das casas rurais paulistas seiscentistas, identificando nestas a presença de "constantes" tipológicas tais como: a planta retangular; paredes de taipa de pilão; telhado de quatro águas e coberturas com telhas de canal; implantação sobre plataforma natural ou artificial, a meia encosta, nas proximidades de um riacho; planta organizada em três faixas (social, familiar, de serviço, a partir da fachada principal); depósito ou sobrado, aproveitando a acentuada inclinação do telhado; presença de alpendre encravado na fachada principal, entre dois cômodos (capela e dormitório de hóspedes). Classificou os exemplares em dois grupos, o dos exemplares "puros" nitidamente seiscentistas, onde todas as constantes estavam presentes; e o dos exemplares tardios, nos quais algumas constantes teriam desaparecido em decorrência da degeneração do sistema social e econômico consolidado no planalto de Piratininga.

O partido arquitetônico da casa foi justificado em termos sociológicos e econômicos, de modo a ficar demonstrada a sua correspondência com as condições históricas de São Paulo do século XVII. Segundo Saia, o Sítio do Padre Inácio, com sua construção quadrangular, acachapada, definida e segura possuía integralmente as soluções plásticas e técnicas que melhor representavam a psicologia e a situação social do seu dono, o fazendeiro paulista "agenciador de bandeiras, senhor absoluto do sertão desbravado, dono das terras, da família e da escravaria, distribuidor de justiça e de religião" (SAIA 1944, p 272) (Figura 1)

E quando desapareceram aquelas condições econômicas e sociais, o esquema arquitetônico também teria perdido a sua firmeza, a sua definição:

"É sobretudo na aliança das paredes de taipa como telhado de quatro águas que reside a característica mais firme desta arquitetura. Aliança que se manteve rígida enquanto durou o prestígio daquele tipo de colono. E se esfacelou quando a descoberta do ouro veio destruir o prestígio dos paulistas. Mais tarde, mesmo rico e poderoso, nunca mais pôde o fazendeiro restabelecer o mesmo esquema social (...). Terá usado, também, a construção de taipa, mas (...) sem aquela limpeza construtiva do século XVII. Em geral se perde em acréscimos, telhados suplementares." (SAIA 1944: 271)

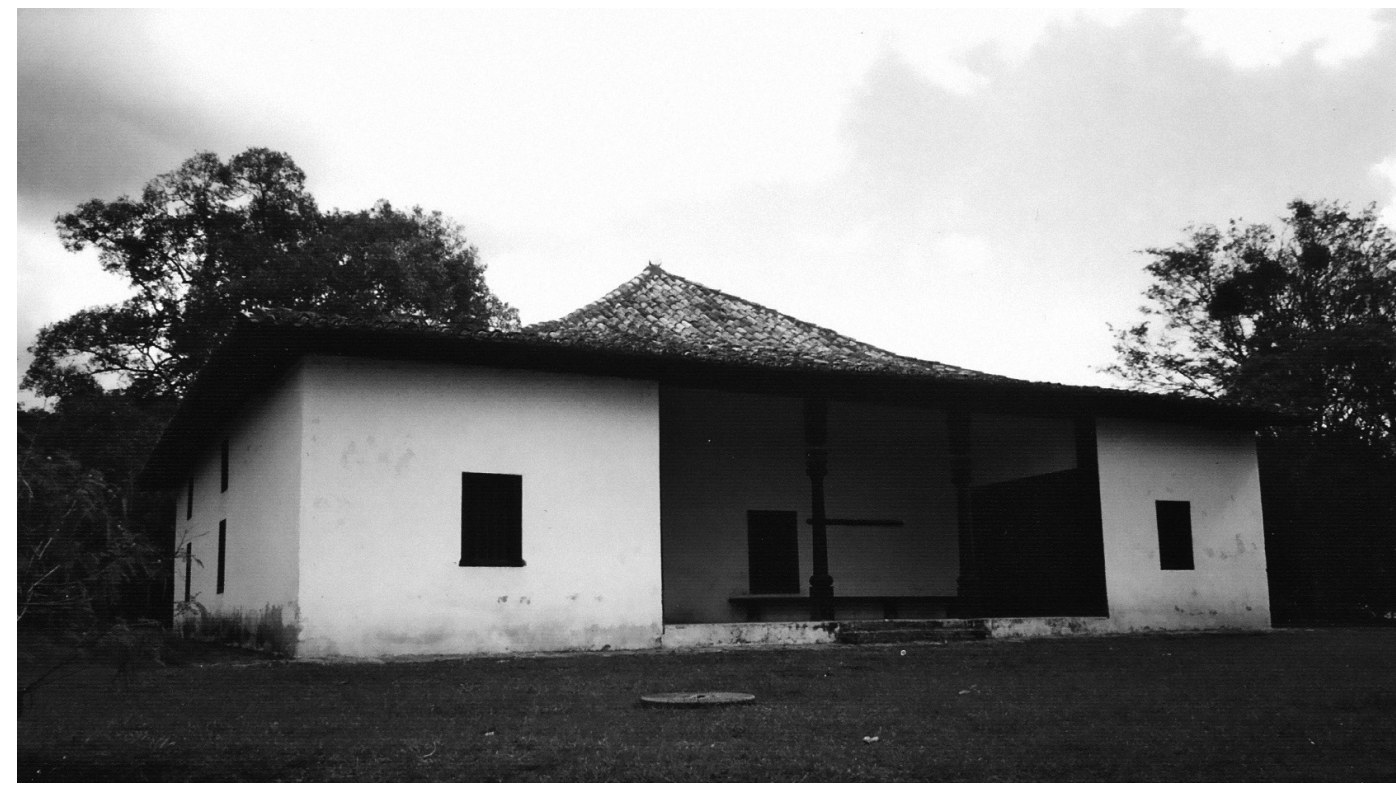


Durante o ano de 1954 a Comissão do IV Centenário da cidade de São Paulo empreendeu a restauração de uma dessas residências, a casa do Butantã. Luís Saia, que dirigiu as obras como diretor do IPHAN no estado, foi solicitado a escrever um texto a respeito da casa. Foi publicado então pela Comissão, em 1955, A casa bandeirista - uma interpretação. Nesse trabalho, publicado onze anos depois do primeiro ensaio de Saia ("Notas"..., 1944), a casa rural de 1944 já aparece como "casa bandeirista". Aqui, sustentando a mesma tese original da pureza e da decadência do tipo arquitetônico, Saia a demonstra em termos mais enfáticos, dando destaque à participação do fenômeno da mestiçagem cultural na formação da sociedade piratiningana. Explicada a origem étnica do povo paulista, o autor passa a caracterizar a solidez da sociedade bandeirista em todo seu apogeu, e relaciona a ela a emergência do fenômeno arquitetônico bandeirista puro. Depois, aplicando a noção evolutiva de "apogeu - decadência", relaciona a desagregação do sólido quadro sócio-econômico à equivalente deterioração do tipo arquitetônico puro.

O texto é da maior importância para compreendermos alguns aspectos ideológicos envolvidos nas restaurações das casas bandeiristas. Em primeiro lugar, a tese da mestiçagem: através da mistura dos elementos português e índio, a mestiçagem teria sido responsável por permitir a criação de estratégias de sobrevivência, guerra e povoamento, num ambiente hostil e estranho ao colono português. Ela teria possibilitado também a realização do " talvez único ciclo econômico social inteiramente nacional". Ou seja, no planalto paulista teria se desenvolvido o único modelo colonial de povoamento livre de influências extra-lusitanas e extra-indígenas, e nisto residiria a singularidade do quadro paulista, que Saia desejava valorizar no cenário do patrimônio histórico nacional

Saia enfoca o período de apogeu da atividade bandeirista, o século XVII, como aquele em que " todos os quadros da sociedade bandeirista estão desenhados, com fisionomia própria e sólida".

No período de apogeu teria se chegado também à solução arquitetônica perfeita, através do ajuste de formas européias às novas condições ambientais, e da definição dos programas, da pesquisa das soluções plásticas, da escolha dos melhores e mais adequados materiais, das argilas e das madeiras.
Assim como o apogeu do quadro social terminaria por entrar em decadência no decorrer do século XVIII, também a arquitetura teria se sujeitado a acolher soluções "estranhas à sua formação", decaindo juntamente no decorrer do século XVIII. Explicarse-iam desta forma a existência de exemplares desconformes com o padrão "puro", tais quais os Sítios Mandú, Caxingui e Butantã, com alpendre posterior; ou o Butantã, ainda, sem grades nas janelas e com vergas arqueadas; ou o Tatuapé, com capela encostada na casa, tudo isto "soluções desconformes e arranjadas", " plantas que perderam a simplicidade e a limpeza" (SAIA 1955, p 13).

Nas restaurações, a tese do tipo arquitetônico "puro" legitimou aquelas intervenções orientadas para a recuperação da imagem "pura", autorizando a destruição de elementos arquitetônicos desconformes com o padrão. Essa recuperação foi orientada também pelo desejo modernista de exaltar as raízes da cultura paulista e de remover dos exemplares, sempre que possível, os traços da "decadência" social, cultural e estilística.

Deve ser lembrado, contudo, que a valorização positiva da sociedade bandeirante e de suas bases étnicas e sociais mamelucas não foi uma construção ideológica de Saia. No século XVIII Pedro Taques de Almeida Paes LEME (Nobiliarquia Paulistana Histórica e Genealógica, 1769-1774) e Frei Gaspar da MADRE DE DEUS (Memórias para a história da Capitania de São Vicente, 1797) já haviam exaltado a coragem dos bandeirantes através de narrativas de fatos heróicos, e nobilitando o mameluco pelo exercício militar e pela sua participação no episódio das bandeiras que, por sua vez, aparecem como fatores de expansão do território e de enriquecimento da colônia. Afonso de Escragnolle TAUNAY, em História Geral das Bandeiras Paulistas (1924-1950), destacara a importância das bandeiras na conquista territorial e nos descobrimentos das minas de metais e pedras preciosas. Em Raça de Gigantes (1926), Alfredo ELLIS JUNIOR, tratara da história das bandeiras e dos bandeirantes em termos de "raça" superior e corajosa. Paulística (1925), de Paulo da Silva PRADO, confirma a crença gentílica de quase todos os autores que escreveram anteriormente sobre as bandeiras, valorando o caráter mestiço original da população paulista para valorar o próprio presente. Escreve o autor: "esse cunho mameluco é a nota aristocrática do Paulista puro" (PRADO 1934: 179), frase que 
desperta a nossa curiosidade, pois pretende colocar aristocracia onde ela nunca existiu.

Mas foi 1954, ano do IV Centenário de São Paulo, a oportunidade oficial para os paulistas afirmarem a sua superioridade política e econômica sobre o restante do Brasil. Foi também a oportunidade para todas as elites se afirmarem, tanto a elite industrial, formada por muitos imigrantes, "novos paulistas", como as tradicionais elites "de sangue", os quatrocentões. O caráter industrial, cosmopolita e "progressista" da cidade era motivo de orgulho geral. Diante do quadro de diversidade cultural da grande cidade, o conceito de "raça" transformou-se, no discurso oficial passando a ser entendido como questão não mais de sangue, mas de "cultura". O conceito de "povo paulista" permitiu reunir a diversidade num só grupo cultural, que trabalharia orientado para um mesmo objetivo: o crescimento econômico e político da cidade e do estado. Mais uma vez as figuras da bandeira e do bandeirante foram ressuscitadas, para serem transformadas, pelo olhar da época, os anos 1950, em entidades míticas, nobres e dignas de pertencerem à ancestralidade paulista. O passado deveria parecer rico e altivo, para ser motivo de orgulho, e não de vergonha. Estava, portanto, definida a temática das comemorações do IV Centenário. Os símbolos significantes do caráter de São Paulo eram: o índio, o bandeirantismo e o crescimento industrial e urbano.

Em palestra de 1961, "Roteiro dos Monumentos Históricos e Artísticos de São Paulo" proferida no curso "Arte Antiga no Brasil"11, Saia aventou a idéia de o projeto das casas bandeiristas terem tido como modelo de desenvolvimento as ville de Palladio. O tratamento erudito, a proximidade cronológica e a sistematização dos exemplares brasileiros levaram Saia à conclusão de que teria ocorrido uma derivação de padrões a partir de uma matriz italiana. A publicação do tratado de Palladio, em 1570, teria difundido o modelo das vilas italianas nas Américas. A regionalização do modelo teria implicado um retrocesso do estágio palladiano para um nível primitivo, natural para territórios de colonização recente, mas a singularidade de ter atingido um alto grau de refinamento técnico dentro dos limites impostos pela condição colonial, refinamento possibilitado segundo Saia, novamente, pela riqueza, poder político e estabilização do esquema social bandeirista.
Posteriormente, a tese palladiana foi questionada em várias ocasiões, contraposta à tese de uma possível procedência portuguesa do partido (Carlos LEMOS em "A Casa Colonial Paulista", 1974), ou hispânica (Aracy AMARAL, A Hispanidade em São Paulo, 1981), ou ainda italiana de filiação militar (Victor Hugo MORI, Arquitetura Militar, 2003). Além disso, a partir da análise de inventários e testamentos, Carlos Lemos e Ernani Silva Bruno observaram que inexistia a diferença tipológica, citada por Luís Saia, para edificações da primeira e segunda metade do século XVII (BRUNO 1977, p 59). Daí Lemos discordar da tese original de Saia, e afirmar em Casa Paulista que desde o primeiro século existiram casas rurais de partido arquitetônico bandeirista envolvendo muitas variações na disposição dos corredores (alpendres), e das cozinhas; enfim, que não foi possível "de modo algum obter uma cronologia envolvendo critérios de organização da planta da casa roceira bandeirista." (LEMOS 1999: 21-27). Lemos crê que o exame realizado em apenas doze exemplares arquitetônicos, conforme fez Saia, seria insuficiente para estabelecer qualquer teoria cronológica sobre a evolução ou decadência daquele tipo arquitetônico.

\section{O paradigma técnico e ideológico}

Além de ter sido o primeiro a caracterizar histórica e arquitetonicamente as casas bandeiristas em 1944, Saia foi também quem, representando o IPHAN em São Paulo, iniciou as restaurações naqueles edifícios com a intervenção no Sítio Santo Antônio em 1940.

As restaurações serviram à delegacia regional do IPHAN em São Paulo como oportunidade de pesquisa e aplicação de conceitos teóricos e técnicos, além de estudo dos edifícios propriamente ditos. Muitos dos pressupostos colocados na tese de 1944 e no texto de 1955 são decorrência da intimidade de Saia com as casas bandeiristas, adquirida durante a restauração destas.

A experimentação no Sítio Santo Antonio foi fundamental para o estabelecimento de um conceito de restauração das casas bandeiristas, no que diz respeito ao partido arquitetônico geral, compreendendo aspectos programáticos, plásticos e técnico-construtivos. Recompôs-se pela primeira vez a planta "pura" da residência rural seiscentista, 
justificada posteriormente na tese de 1944. Foi nessa obra que se trouxeram pela primeira vez, para as residências bandeiristas, o esqueleto de concreto armado e as placas de concreto ciclópico já empregados anteriormente na Igreja do Rosário do Embu (1939) e na Igreja de São Miguel Paulista (1939). Foi também o momento pioneiro de estabelecimento de um conceito de ambientação das residências bandeiristas, orientado para a composição paisagística do entorno imediato daquele tipo de monumento, liberando o edifício isolado de quaisquer anexos e acréscimos desconformes com a noção de planta fechada. A operação de demolição da casa do Barão de Piratininga, construção novecentista semi-arruinada existente ao lado da casa sede à época da restauração, é exemplar do conceito de liberação do monumento.

A experiência adquirida pelo IPHAN em São Paulo, nas obras pioneiras da Igreja de Nossa Senhora do Rosário, Igreja de São Miguel Paulista e Sítio Santo Antonio, estabeleceu um corpo conceitual teórico e técnico respeitante à restauração dos edifícios de taipa de pilão que o próprio IPHAN transformou em paradigma quando passou a adotá-lo em todas as restauração subseqüentes.

Segundo José Saia Neto os experimentos com o concreto armado na consolidação de monumentos iniciaram-se, por iniciativa de Luiz Saia, na restauração da Igreja de Nossa Senhora do Rosário. A restauração da igreja do Embu foi uma das primeiras obras do IPHAN em São Paulo, e a primeira experiência de consolidação de paredes de taipa (ROMAN 2003, p 308).

A partir das experiências pioneiras, o IPHAN difundiu o emprego do concreto armado na restauração por todo o país. O concreto foi usado em substituição a frechais, vigas de cumeeira, terças, enfim, ao madeiramento pesado das coberturas. Em Pernambuco (onde Ayrton de Carvalho, engenheiro, era o delegado do IPHAN), na Bahia e em Minas Gerais, por exemplo, executavam-se peças de cobertura em concreto, em nome da durabilidade da solução construtiva, e também "do respeito às recomendações emanadas das Cartas de Atenas e de Veneza, que preconizavam o emprego de materiais novos nas restaurações a fim de deixar visível a intervenção", conforme explicava aos alunos o arquiteto Fernando Machado Leal em seus cursos sobre técnicas de restauração de monumentos brasileiros, na década de 1970. O engenheiro calculista Joaquim Cardoso, colaborador do IPHAN, era chamado a opinar em situações complexas, e sempre recomendou consolidar as estruturas desestabilizadas com o auxílio de estruturas de concreto armado e/ou tirantes de aço quando fosse o caso. No caso da taipa, era usual proteger o respaldo das paredes com uma laje de concreto (também armado para cintar as paredes), para evitar uma desagregação eventual advinda de infiltração de água de chuva. (LEAL 1977, pp. 41, 131).

A atualidade e a distinguibilidade do concreto armado eram também usadas como justificativas para o seu emprego. Não só por razões técnicas, mas também ideológicas, o uso do concreto tornou-se uma solução técnica aceita em todas as restaurações do IPHAN. Afinal, a experimentação com o concreto era sem dúvida uma maneira "moderna" de intervir nos monumentos. Explorar os recursos do concreto armado nas restaurações era, naquelas circunstâncias, uma opção inevitável (Figuras 2, 3 e 4).

Nas casas bandeiristas, Luís Saia introduzia peças de concreto, armado ou não, de variadas maneiras, dependendo da avaliação que fazia da situação de estabilidade estrutural do sistema como um todo - sistema entendido como paredes e cobertura trabalhando conjuntamente. O método concebido por Saia usava o concreto para três finalidades objetivas.

Primeiramente, as peças de concreto armado serviam diretamente à estabilização e consolidação estrutural, através de um esqueleto de concreto armado inserido nas paredes de taipa (Figura 4). Segundo, as peças de concreto ciclópico ou de concreto comum serviam ao preenchimento de lacunas e assim, indiretamente, também à consolidação estrutural, na medida em que preenchiam vazios e passavam a permitir novamente o descarregamento de cargas através delas (Figura 5). Terceiro, Saia concebeu placas de concreto para contornarem todo o perímetro externo da construção numa faixa de 60 centímetros de altura média a partir do solo, como solução para impermeabilizar os muros contra a erosão provocada por respingos de água de chuva caídos do beiral (Figura 6). 

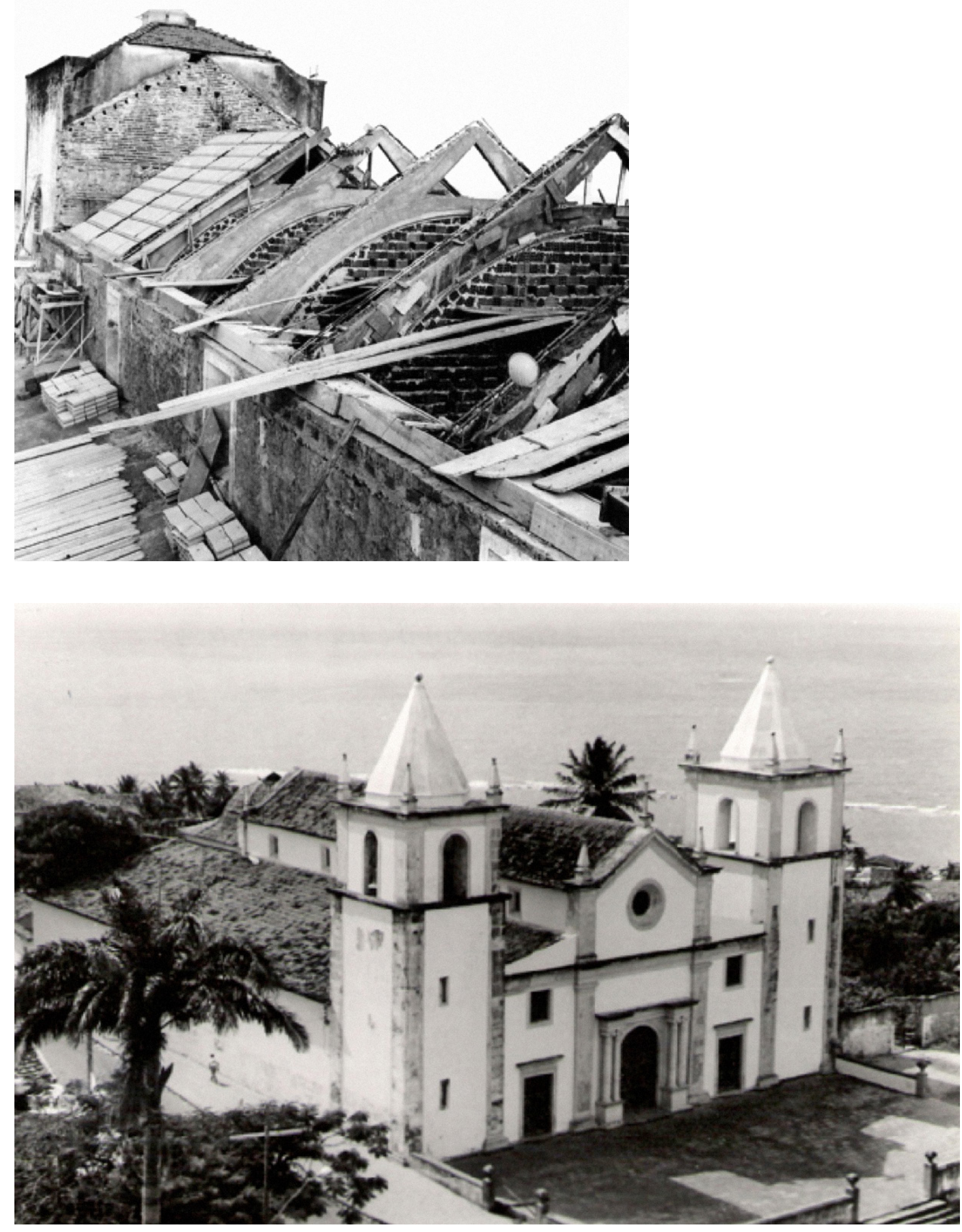

Figura 2 (topo): Sé de Olinda durante a restauração. Madeiramento do telhado substituído por estrutura de concreto armado. Fonte: Arquivo FUNDARPE.

Figura 3: Sé de Olinda, após a restauração. Fonte: Arquivo FUNDARPE. 


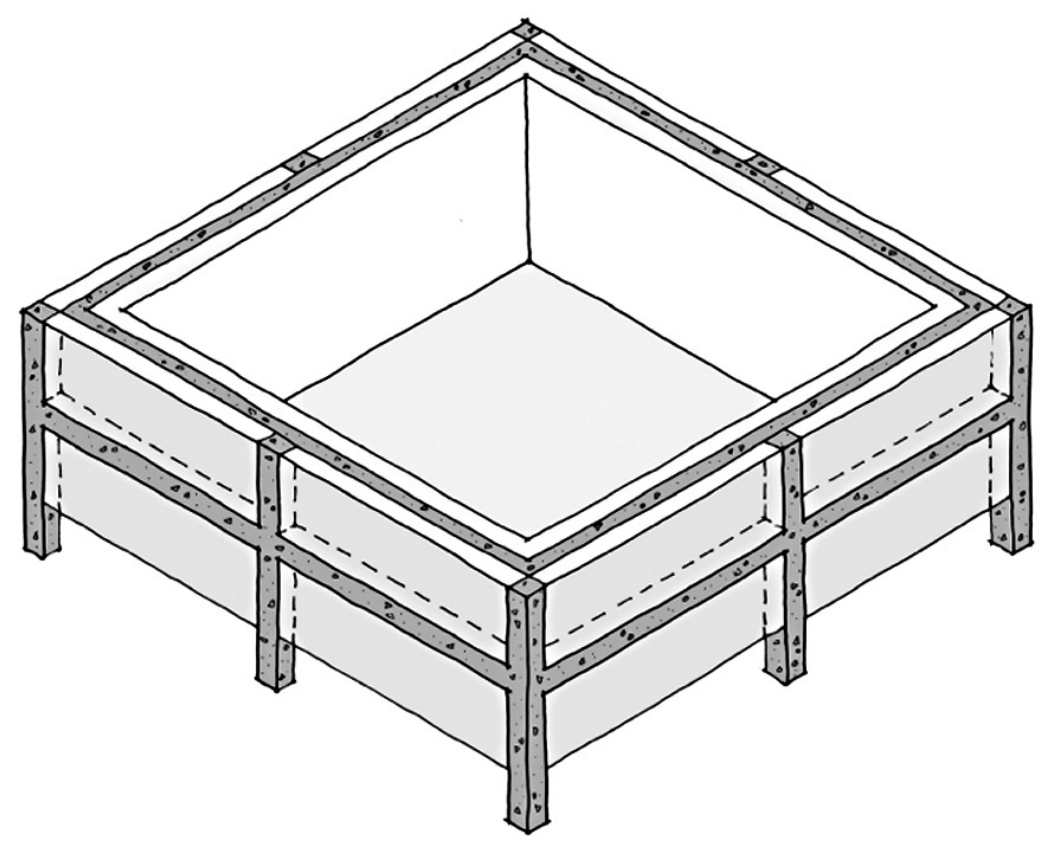

Figura 4 (topo): Esquema do esqueleto de concreto armado. Fonte: Desenho de Tatiana Cipoli, com base em croquis de Lia Mayumi.

Figuras 5 e 6: Casa do Butantã. Preenchimento com concreto, de lacunas na taipa. Formas preparadas para início da concretagem. 1954. Fonte: Caderno de Obras Casa do Bandeirante. Acervo PMSP/Pres.
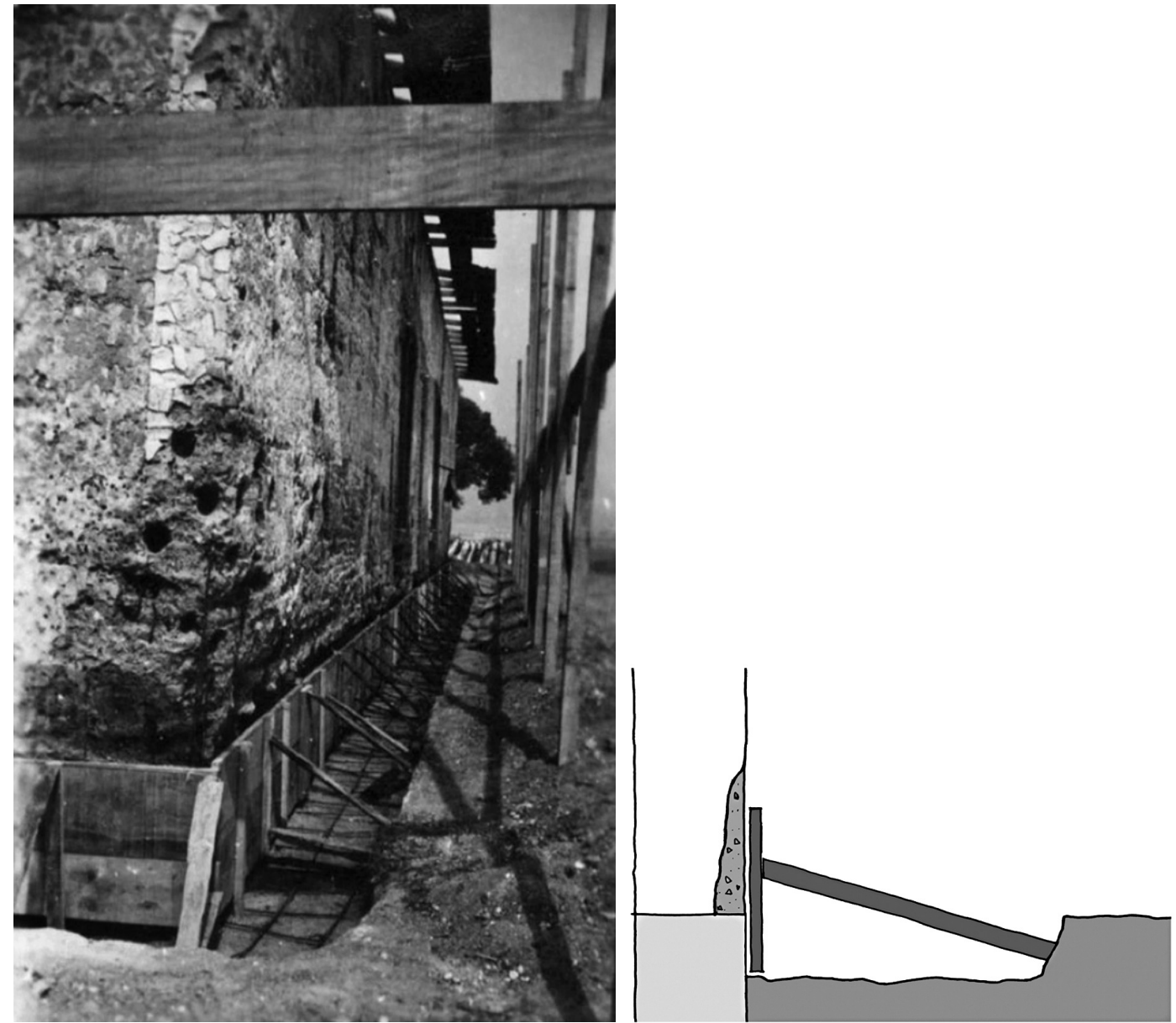
12 Carta de Atenas, dos CIAM - 1933. In: IPHAN. Cartas Patrimoniais. Brasília: IPHAN, 1995. Caderno de documentos n. 3. pp. 23-79.

13 IPHAN - 9a. Coordenadoria Regional, São Paulo. Sítio e Capela de Santo Antônio. Roteiro de visita. São Paulo: IPHAN 9a. CR, 1997. Projeto "Implantação de Programas de Uso em bens Tombados".

Figura 7: Sítio Santo Antonio. Gramado, lago e mata no lugar da roça. Fonte: fotografia gentilmente cedida por Maria Lucia Perrone Passos, 2004.
Do ponto de vista estético, Saia recomendava o concreto em substituição aos encamisamentos de tijolos de barro - que eram usado até então como paliativos tradicionais para preencher partes erodidas/ lacunas - devido à sua plasticidade, que permitiria a concretagem de paredes com aspecto irregular, como é típico da taipa (SAIA 1944, p 54).

E, finalmente, do ponto de vista conceitual, à diferença do colega do IPHAN Fernando Machado Leal que se apóia em princípios normativos científicos contidos na Carta de Veneza para empregar o concreto (LEAL 1977, p 131), Saia apóia-se num fundamento ideológico e arquitetônico:

"Do ponto de vista apenas documentário, foi obedecido um preceito da arquitetura moderna: honestidade no uso do material, respeito às legítimas verdades arquitetônicas, que mandam conservar aquelas peças que realmente sejam documentos de uma época e de um povo. Da maneira com que se agiu ninguém, conhecedor de engenharia, pode ser enganado a respeito do processo de restauração, nem a respeito da obra tradicional. " (SAIA 1944, p 55)

O fundamento citado por Saia é claramente inspirado nos artigos 65 e 66 da Carta de Atenas dos CIAM, onde estes estabelecem que "Os valores arquitetônicos devem ser salvaguardados (edifícios isolados ou conjuntos urbanos)" e que eles "Serão salvaguardados se constituem a expressão de uma cultura anterior e se correspondem a um interesse geral" . ${ }^{12}$

Um modo característico de ambientação das residências bandeiristas também faz parte do "modelo tradicional" de restauração. Conforme já foi dito, a supressão da casa do Barão de Piratininga no Sítio Santo Antonio fez parte da primeira experiência de ambientação dessas casas. As duas construções do Sítio - a casa sede e a capela - foram liberadas da construção próxima, de forma a ter sua visibilidade desimpedida. Um grande lago foi criado em frente aos dois edifícios (GONÇALVES 2004, p 109). A roça do sítio foi substituída por um gramado extenso e homogêneo. Sanitários para visitantes foram construídos em local afastado dos edifícios. Posteriormente, foram agenciadas/reflorestadas as encostas dos morros visíveis a partir do sítio ${ }^{13}$. O resultado plástico impressiona pela beleza (Figura 7). Trinta e cinco anos depois da obra, Luís Saia, responsável pela intervenção, justifica-a arquitetonicamente, em nome da composição de um "conjunto". Suas justificativas não explicitam o conceito da intervenção, mas nos permitem de certa forma supor as idéias que estavam por trás delas. Suas palavras são, resumidamente, as seguintes:

"Existia no local uma situação em potencial, que permitiu montar um conjunto e de prevenir (sic) uma possibilidade de uso. O potencial foi transformado em

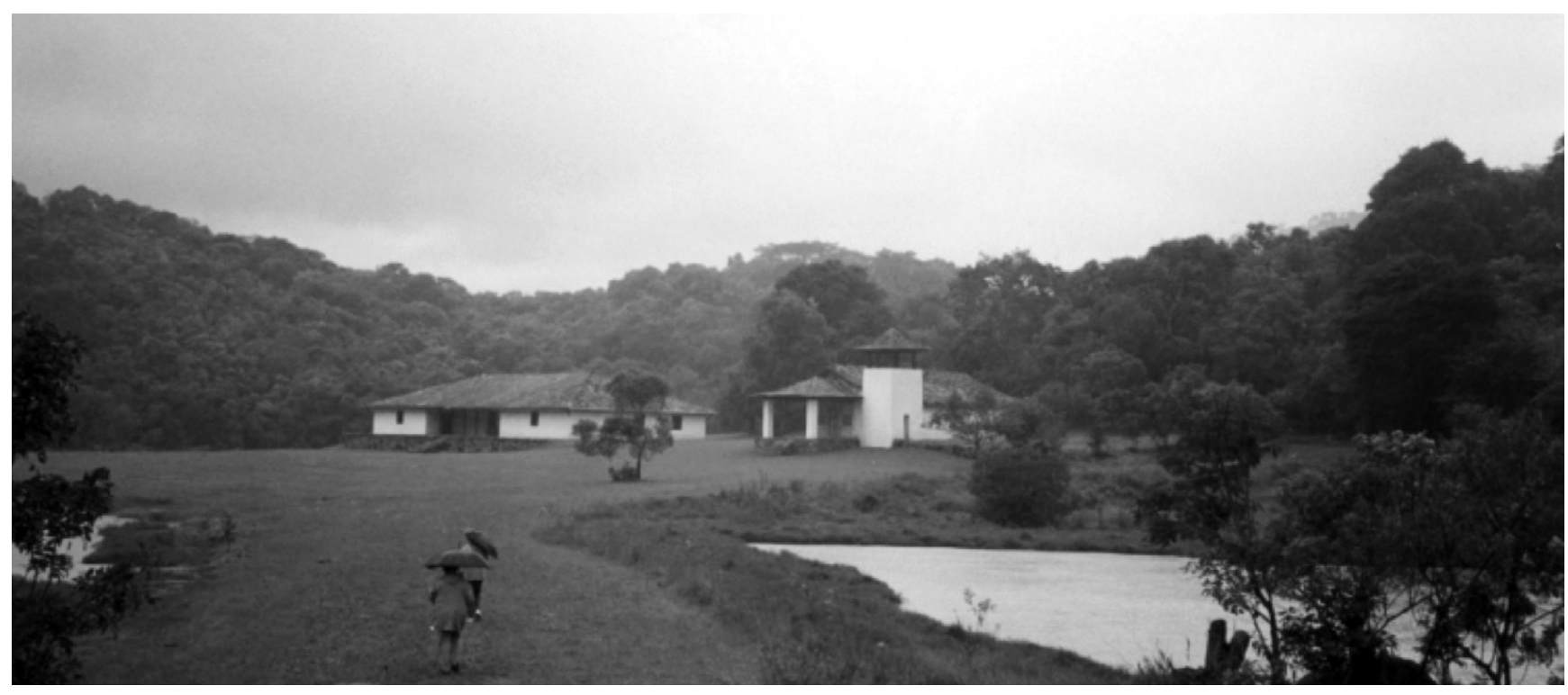


${ }^{14} \mathrm{Cf}$. Curso de Especialização em Conservação de Monumentos e Conjuntos Históricos. São Paulo: Convênio MEC e Secretária de Cultura, Esportes e Turismo do Estado de São Paulo, 1974. Aula de Luís Saia em 6-11-1974.

Figura 8: Casa do Bandeirante, março 1954. Fonte: fotografia de Germano Graeser, Arquivo DPH/Pres./STLP. realidade através de uma série de operações. Um lago que já existia foi aumentado para formar um espelho $d^{\prime}$ água e diminuir a área de tratamento - mato que cresce, com cobra, essas coisas. Achou-se que o melhor tratamento para a área envoltória do monumento seria grama. Como um grande capacho que inclusive evitaria pés de barro na casa. E a experiência provou ser essa a melhor solução. A idéia é formar um conjunto". ${ }^{14}$

O que é possível inferir da intervenção e das palavras que a justificam? Elas levam à conclusão que a mesma preocupação de recuperar uma imagem arquitetônica ideal das edificações também existiu em relação ao ambiente total, que foi moldado para se conformar a um padrão estético desejado.

Luís Saia resgatou o monumento arquitetônico excepcional do seu passado roceiro e não resistiu a transformar o também o ambiente circundante, para realizar uma obra de arte total. A intenção estética, arquitetônica, prevaleceu sobre a severidade plástica que o vestígio histórico por vez impõe.

É inevitável citar mais uma vez a recomendação para o patrimônio histórico das cidades contido na Carta de Atenas dos CIAM, pois na operação de ambientação do monumento também vemos o comprometimento modernista de Luís Saia:
"Nem tudo que é passado tem, por definição, direito à perenidade; convém escolher com sabedoria o que deve ser respeitado. Se os interesses da cidade são lesados pela persistência de determinadas presenças insignes, majestosas, de uma era já encerrada, será procurada a solução capaz de conciliar dois pontos de vista opostos: nos casos em que se esteja diante de construções repetidas em numerosos exemplares, algumas serão conservadas a título de documentário, as outras demolidas; em outros casos poderá ser isolada a única parte que constitua uma lembrança ou um valor real; o resto será modificado de maneira útil."

\section{A "casa do bandeirante"}

A casa do Butantã, mais conhecida como Casa do Bandeirante, foi restaurada em 1954-55, pela Comissão do IV Centenário da Cidade de São Paulo. O projeto de restauração e a orientação técnica ficaram sob responsabilidade de Luís Saia, então chefe do distrito do IPHAN em São Paulo.

Nesta intervenção a abordagem do edifício foi idêntica à das demais obras que o IPHAN havia realizado anteriormente em casas bandeiristas. A intervenção inaugurou o ciclo de restaurações de casas bandeiristas da Prefeitura de São Paulo, e estabeleceu o modelo de intervenção nesses

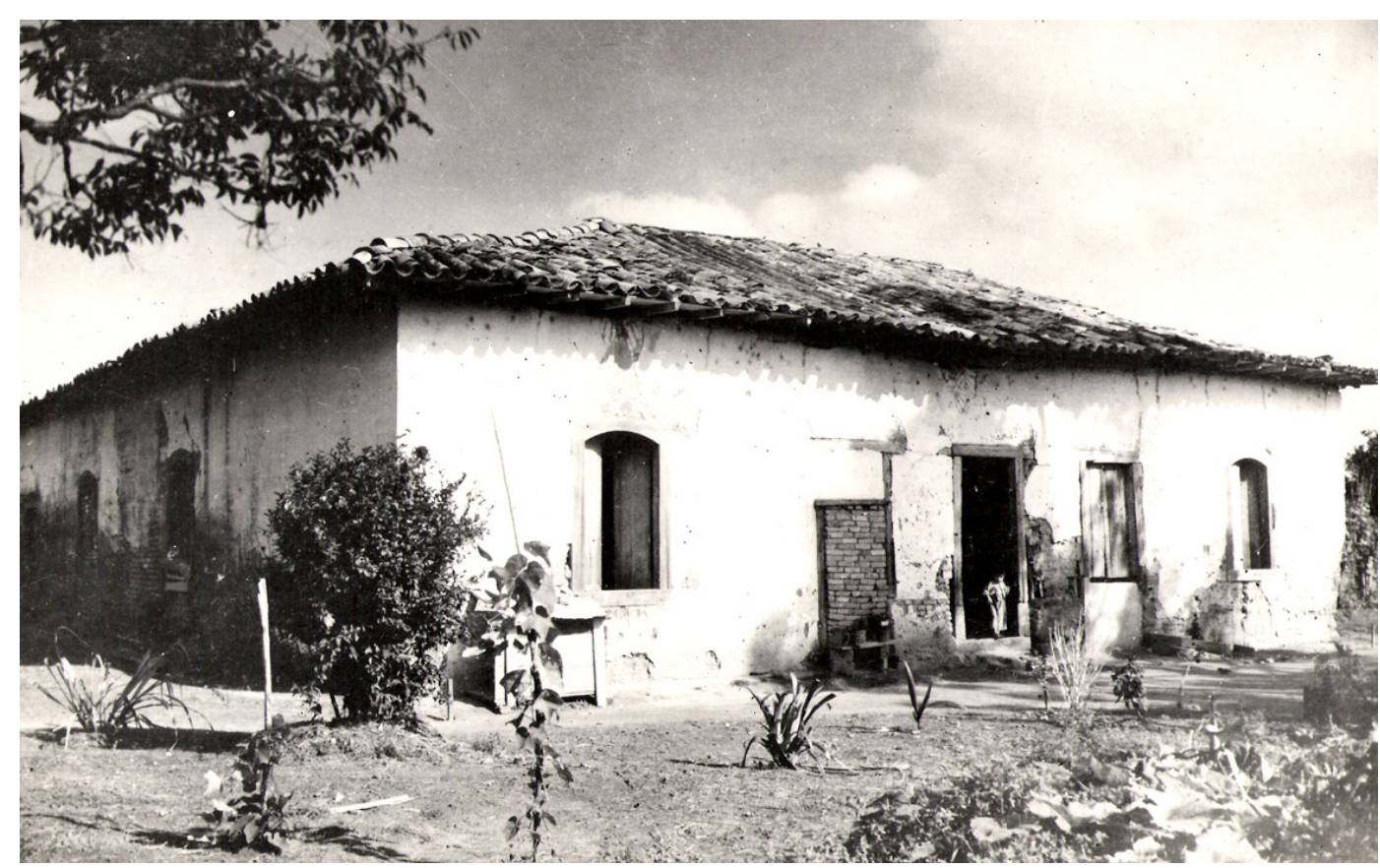




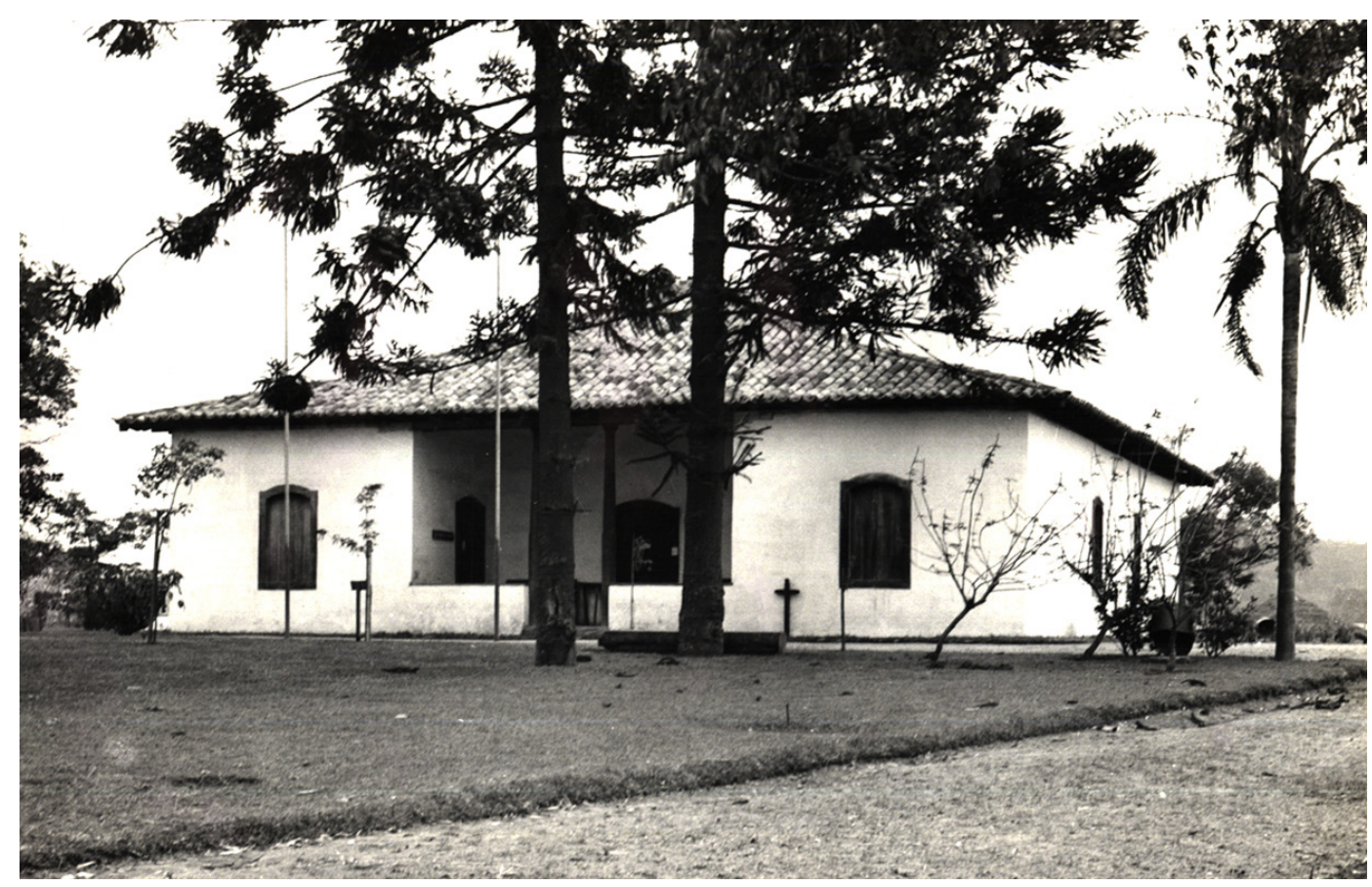

Figura 9: Casa do Bandeirante após a restauração. Fonte: Arquivo DPH/Museu da Cidade, s.d.

15 Escritura lavrada naquela data, no $24^{\circ}$. Tabelião. Cf. Processo municipal 64.988/47, fl. 99 vo. exemplares. A casa do Butantã é uma daquelas casas consideradss "abastardadss" segundo a classificação original de Luís Saia, devido à presença, nela, de dois alpendres e de envasaduras com vergas arqueadas.

Doada pela Companhia City à Prefeitura ${ }^{15}$ desde 20-10-1950, a casa foi invadida em 1951 por várias famílias que ocuparam a casa até o início das obras de restauração. Germano Graeser, contratado pela Comissão do IV Centenário, registrou o estado do edifício em março de 1954. O madeiramento correspondente à área central da casa havia sido removido, restando um pátio central que era usado como galinheiro (Figura 12). As patologias mais freqüentes desse tipo de edificação estavam presentes na casa, com as seguintes características:

1. Erosão das paredes periféricas da casa, restrita à porção inferior próxima ao solo, pela parte externa, devido à água de chuva (Figura 13);

2. Lacunas ("cáries") nas paredes, decorrentes da ação de térmitas, cabodás e desagregação localizada (Figura 14);

3. Fendas e trincas nas paredes, provocadas por desagregações localizadas dos maciços de taipa (Figuras 13 e 14);
4. Separação das paredes de taipa nos cunhais, provocada pela falta de sistema de amarração entre as paredes (ausência de malhetes) e pelo apodrecimento de parte dos frechais (Figura 14);

5. Envasaduras primitivas emparedadas com alvenaria de tijolos ou pau a pique (Figura 13);

6. Envasaduras escavadas nas paredes, onde não existiam primitivamente (Figura 13);

7. Paredes primitivas desaparecidas, e paredes não primitivas de fatura mais recente;

8. Esquadrias alteradas, ou apodrecidas, ou desaparecidas (Figuras 12 e 13);

9. Cobertura alterada, com madeiramento de material, forma (e por vezes solução construtiva) diversos do primitivo (Figura 15).

10. Revestimento ausente ou desagregado em vários pontos (Figura 13);

11. Poucas ferragens primitivas remanescentes. A maior parte estava desaparecida.

A obra aconteceu sem prévio projeto arquitetônico, como de praxe. O partido adotado para a intervenção na casa do Butantã, alicerçado sobre as bases teóricas estabelecidas por Saia em 1944, orientou-se para a recuperação da feição mais primitiva conhecida do edifício. Essa configuração primitiva foi inferida exclusivamente do exame empírico do edifício e dos pressupostos teóricos de Saia explicitados no texto 

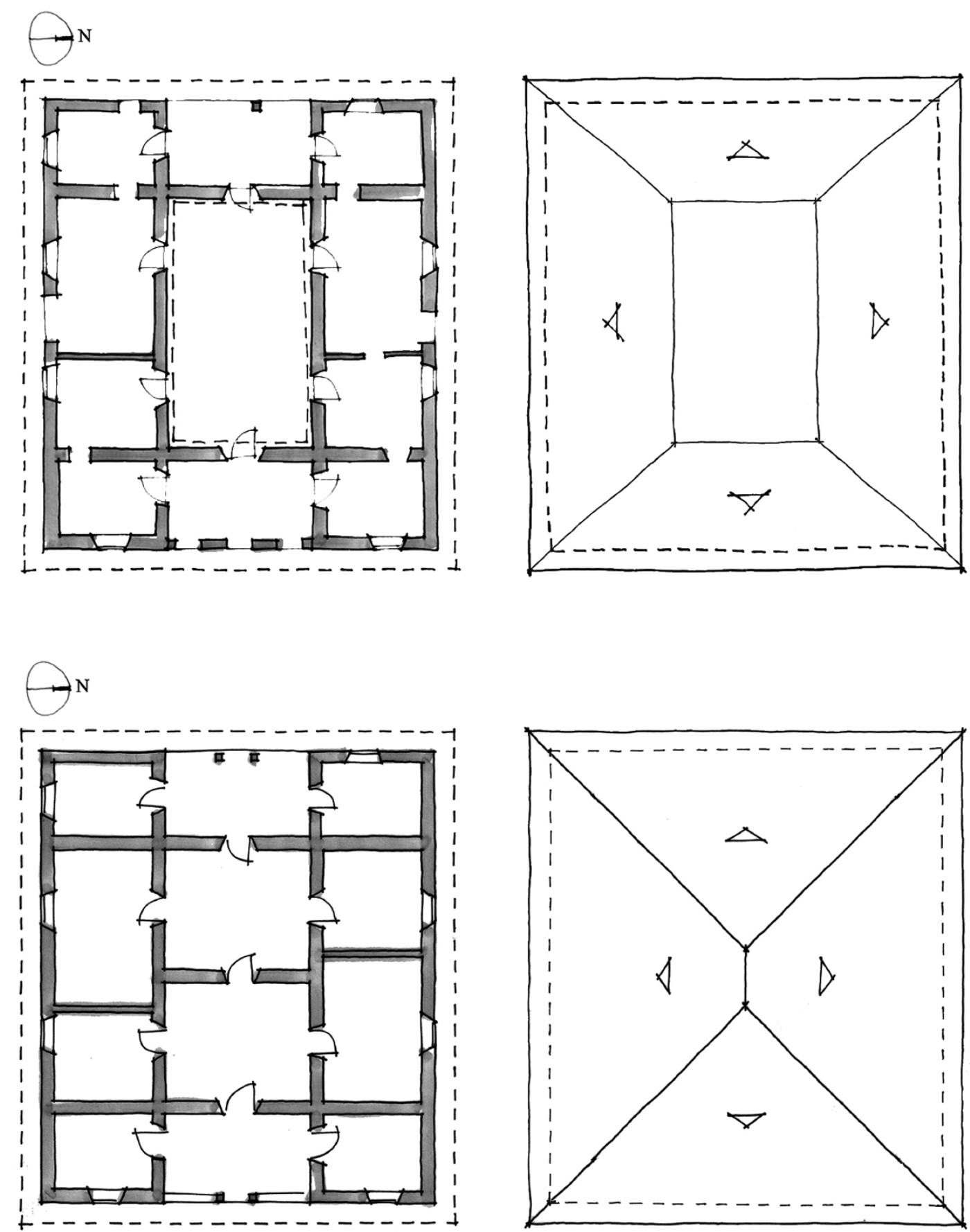

Figura 10 (topo): Planta baixa e do telhado, antes da restauração. Fonte: desenhos de Tatiana Cipoli, com base em croquis de Lia Mayumi.

Figura 11: Planta baixa e do telhado, depois da restauração. Fonte: desenhos de Tatiana Cipoli, com base em croquis de Lia Mayumi. 


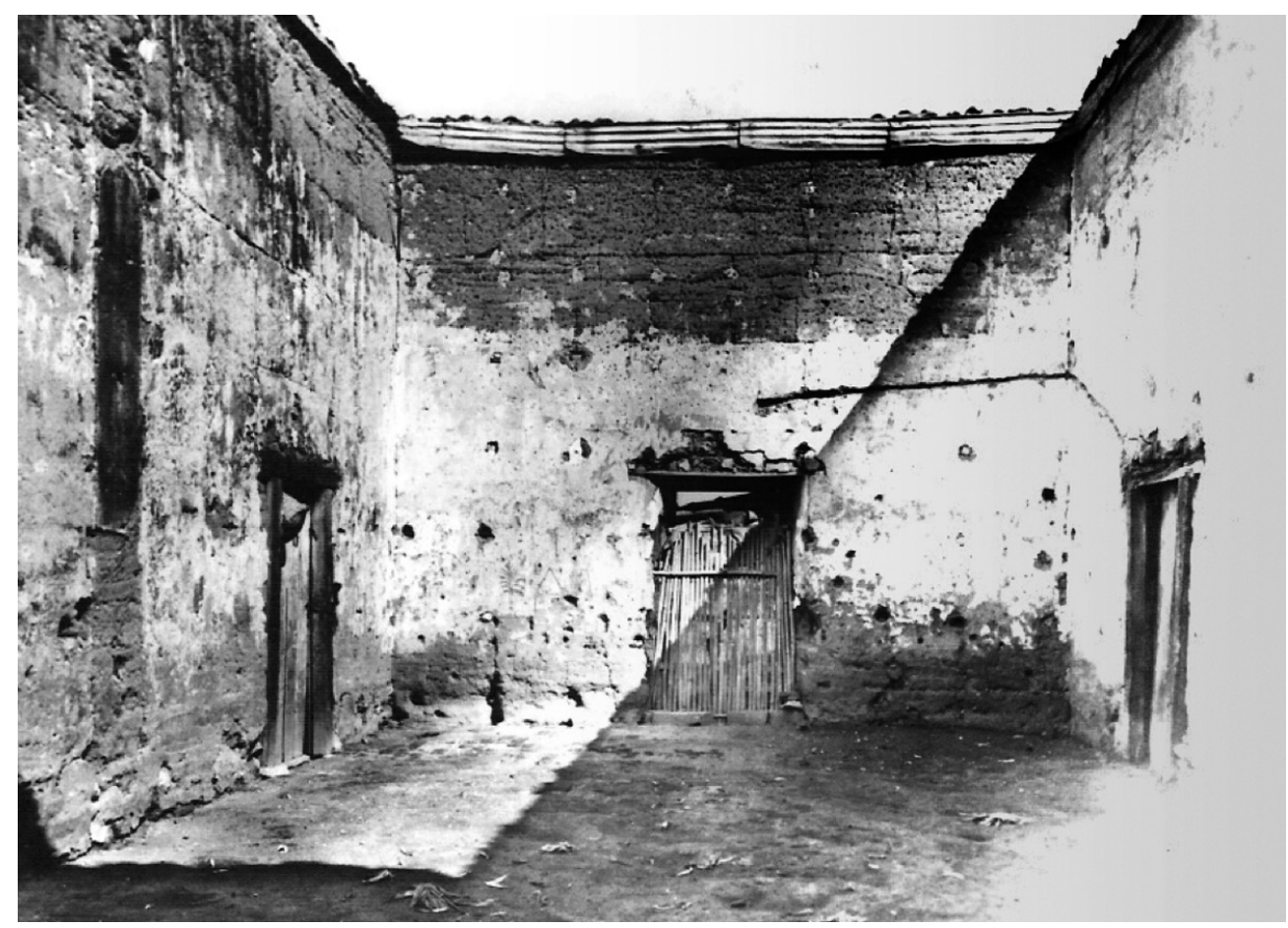

Figura 12 (topo): Casa do Bandeirante - Pátio formado no centro da construção, onde a cobertura fora removida, ou havia desabado. Note-se, no maciço esqurdo, sinal de parede desaparecida. Fonte: fotografia G. Graeser, março de 1954, Acervo PMSP/Museu da Cidade.

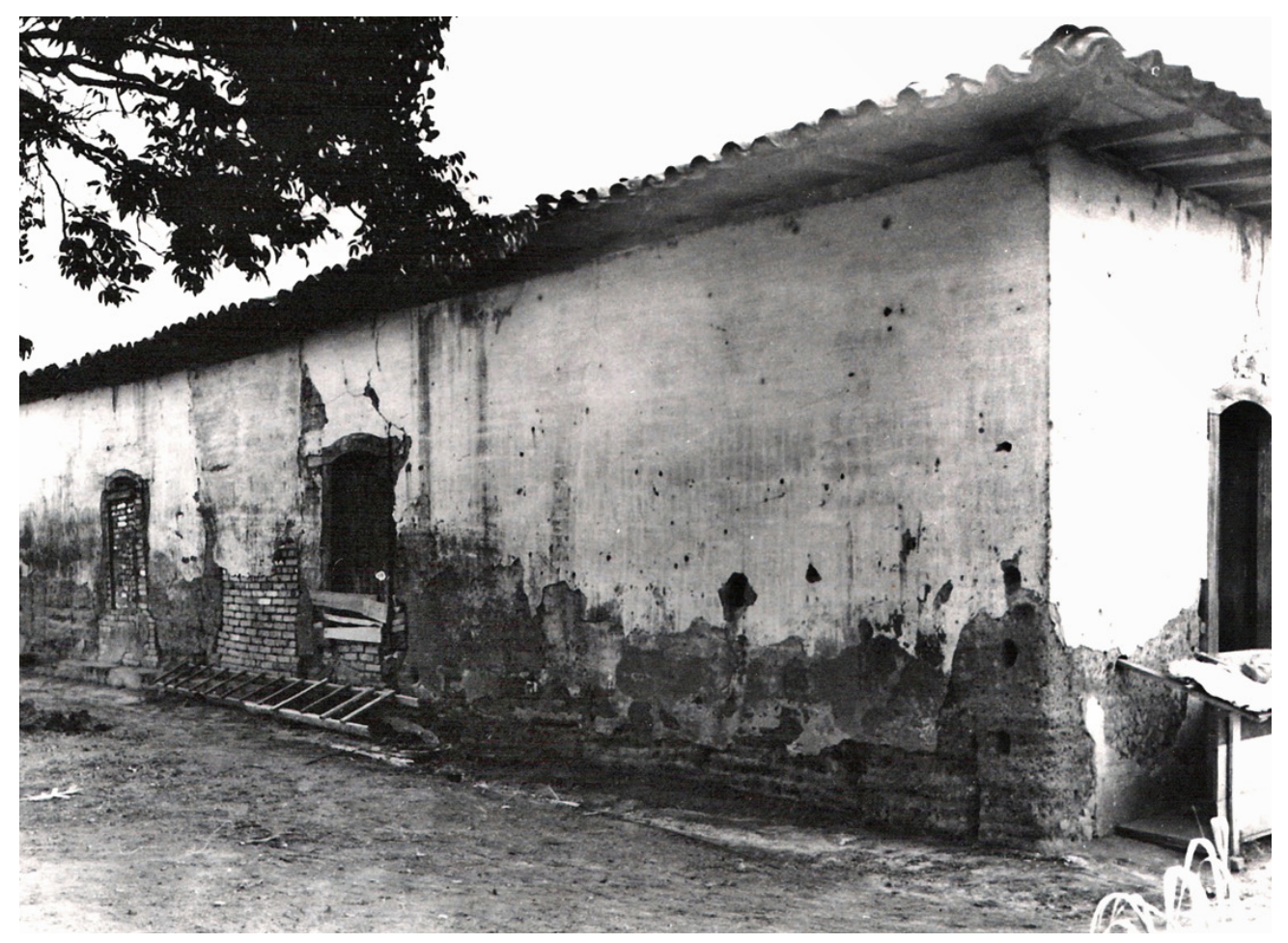

Figura 13: Casa do Bandeirante - Fachada Sul. Base de parede erodida por respingos de chuva. Envasaduras emparedadas. Esquadrias desaparecidas. Lacunas preenchidas com camisas de tijolos de barro. Fonte: fotografia de Germano Graeser, março de 1954, Acervo PMSP/Museu da Cidade. 

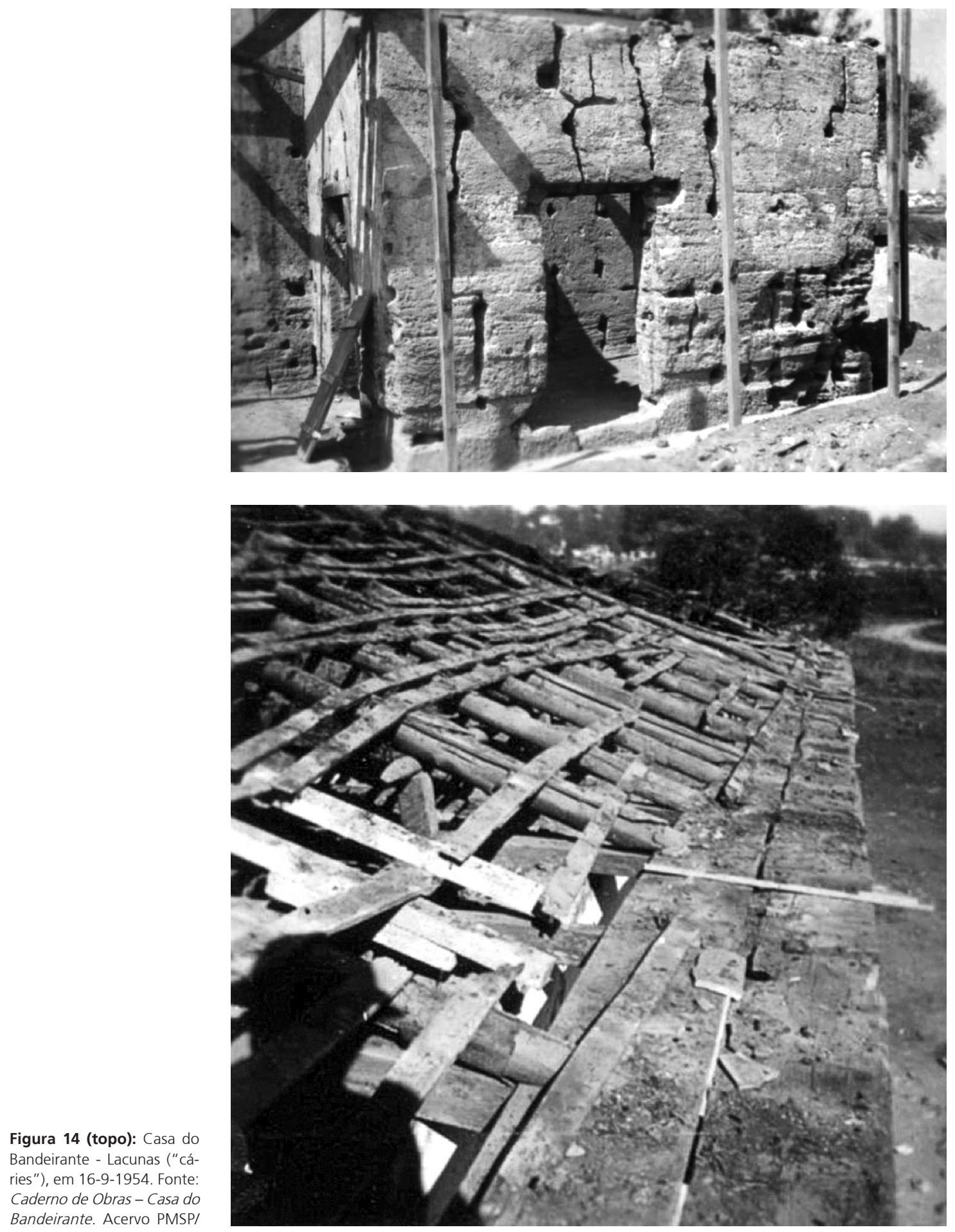

Bandeirante. Acervo PMSPI Pres.

Figura 15: Casa do Bandeirante - Madeiramento leve do telhado desorganizado (forro do beiral, ripas, caibros roliços), no início da obra, em 14-7-1954. Fonte: Caderno de Obras - Casa do Bandeirante. Acervo PMSP/Pres. 
de 1944, como faz supor a ausência absoluta de documentos de pesquisa sobre a história do imóvel (que só veio a ser feita em 1980). Essa pesquisa, aliás, certamente teria merecido atenção do IPHAN caso o edifício não fosse o que era, ou seja, segundo a tese original, somente uma casa muito velha, não tombada, de valor arquitetônico e histórico prejudicado pela sua filiação tipológica tardo-bandeirista.

Apesar da classificação desprivilegiada, a obra mereceu a tradicional abordagem de obras do IPHAN. Tal qual o partido de intervenção, o conceito técnico da intervenção também já estava definido preliminarmente, qual seja: primeiramente providenciar a consolidação estrutural do edifício; depois, restaurá-lo.

A $1^{\text {a }}$. ETAPA da intervenção era voltada à consolidação, que se sobrepunha à investigação do edifício em busca de vestígios que orientassem a recomposição da configuração prístina. Essa

Figura 16: Alpendre fechado por parede de pau a pique, com porta emparedada, antes da desmontagem da parede. Fachada Leste. Fonte: Acervo DPH/ Museu da Cidade. investigação, embora tivesse caráter arqueológico, pretendia exclusivamente encontrar os vestígios mais primitivos, ignorando e descartando vestígios de épocas intermediárias entre o imaginado "primitivo" e o presente visível.
Para examinar o estado de estabilidade estrutural, e também para confirmar e/ou examinar a presença das constantes típicas das residências bandeiristas (basicamente a planta típica e a localização e feição das envasaduras) procedeu-se, como era usual, à demolição total dos revestimentos da taipa. Essa investigação, que recebe o nome de prospecção (empregado até hoje), atingiu a cobertura, através do destelhamento completo do telhado, para o exame do estado de conservação das peças de madeira e dos respaldos das paredes de taipa, além do exame das soluções construtivas.

As prospecções das paredes consistiam em remover completamente os revestimentos, tivesse ele uma ou mais camadas, não importando se ele estava bem ancorado ou despregado da taipa. Sacrificava-se o revestimento para procurar janelas ou portas tapadas, ou marcas de paredes encostadas (ou amarradas, através de malhetes) às remanescentes (Figura 14). Nesta etapa da prospecção das paredes já se eliminam, juntamente com os revestimentos, todos os "acréscimos intermediários", tais como divisórias de pau a pique, paredes e encamisamentos de tijolos e tabiques de madeira desconformes com a tipologia original. Depurava-se a planta da casa e ao mesmo tempo se descobriam vestígios para recompor estruturas primitivas. (Figuras 16, 17 e 18)

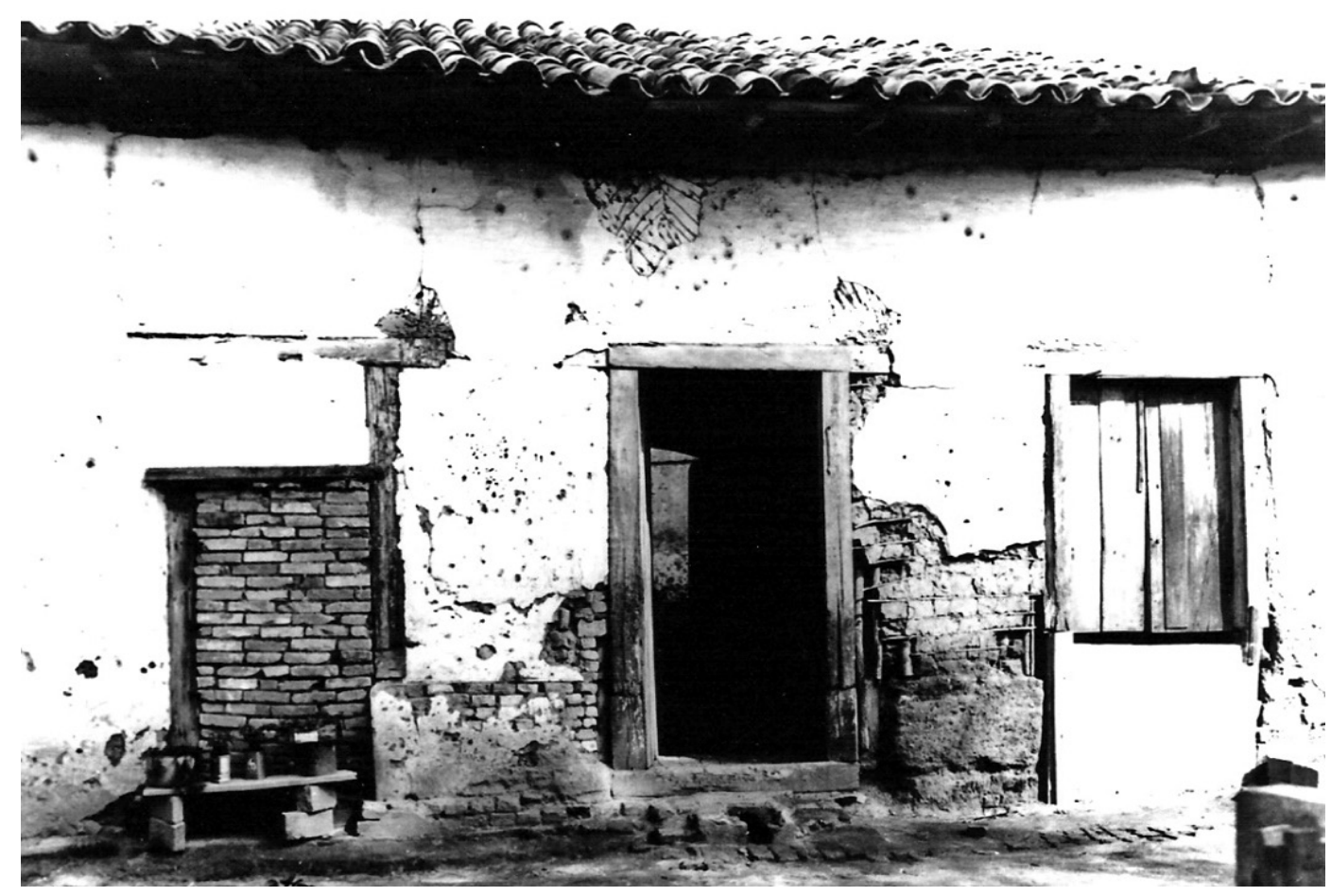




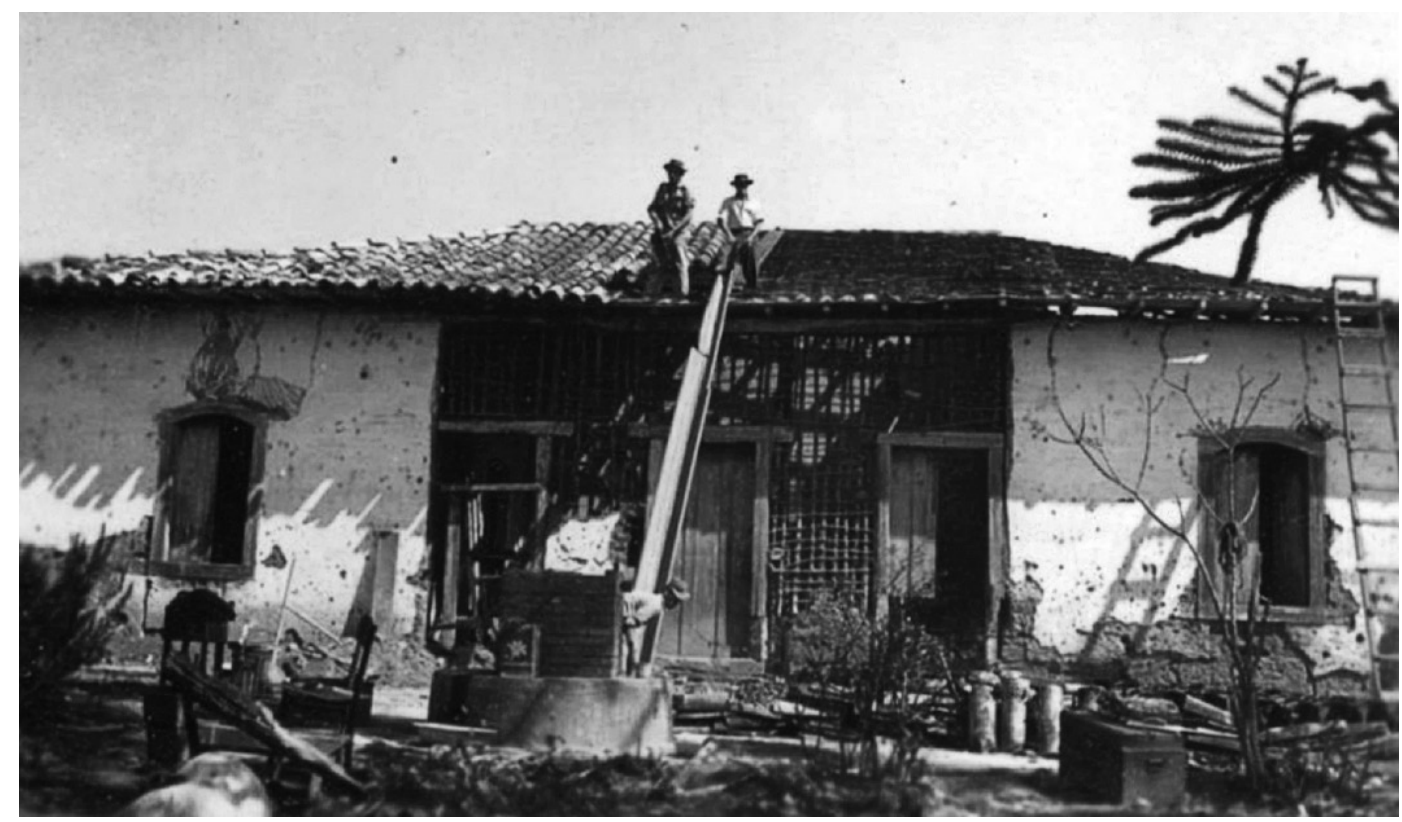

Figura 17 (topo): Desmontagem da parede de pau a pique que fechava o alpendre Leste. Em 30-7-1954. Fonte: Caderno de Obras - Casa do Bandeirante. Acervo PMSP/ Pres.

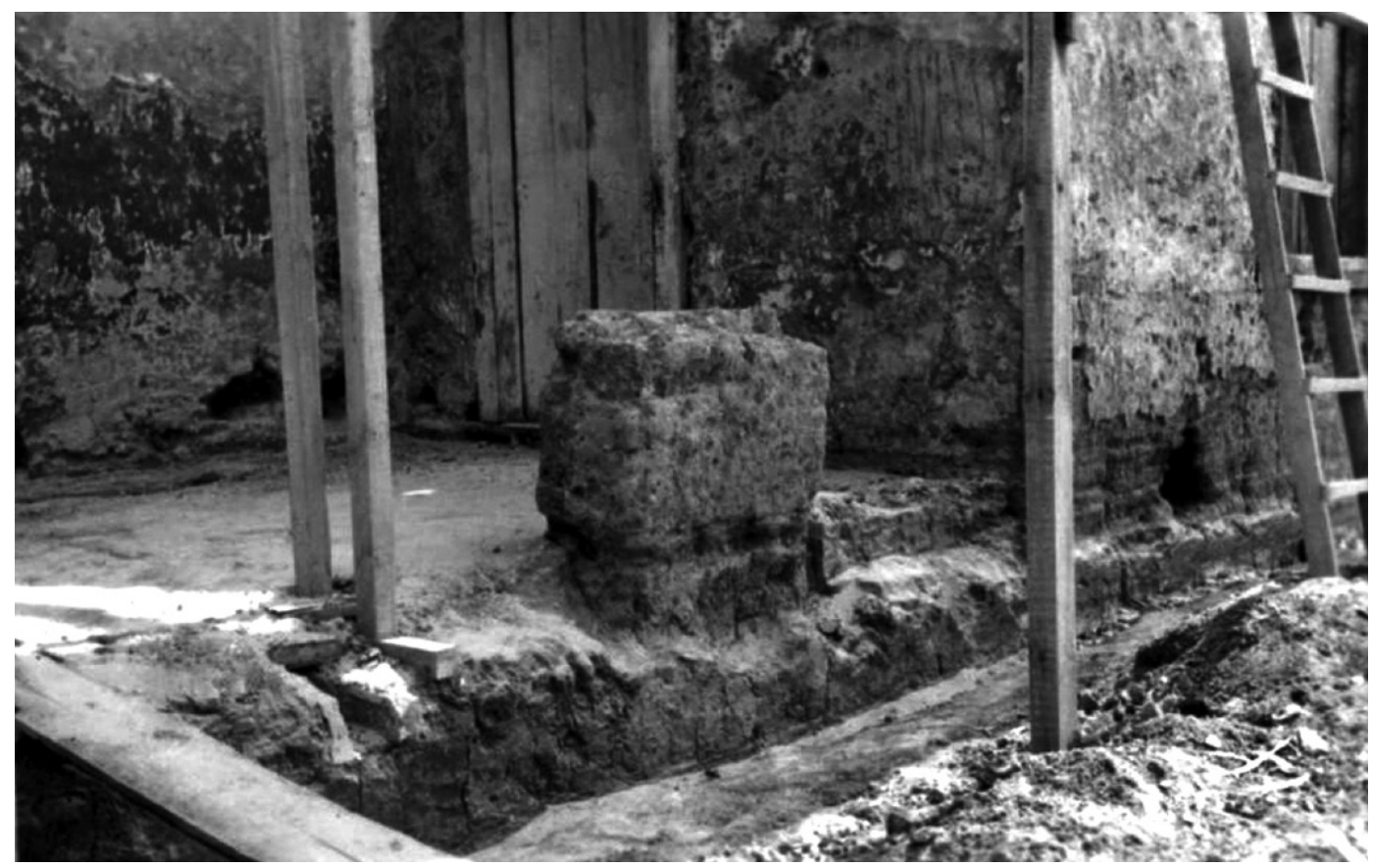

Figura 18: Vestígio de muro de taipa, que autorizou a reconstituição da mureta, revelado após a demolição da parede que fechava o alpendre Leste Em 24-8-1954. Fonte: Caderno de Obras Casa do Bandeirante. Acervo PMSP/Pres. 


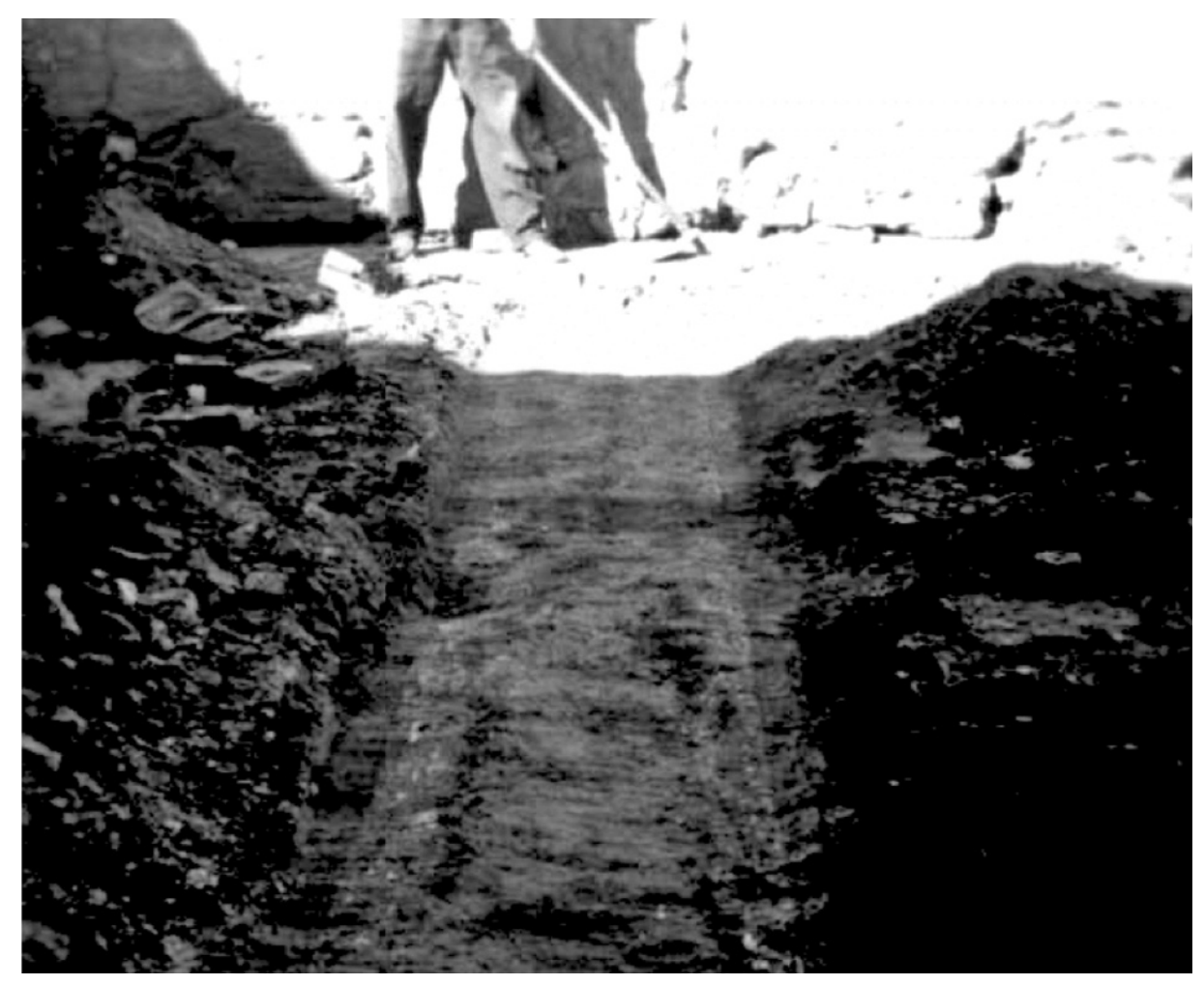

Figura 19: Alicerce já descoberto, de parede que existiu no cômodo central (Ver Figura 12). Em 10-7-1954. Fonte: Caderno de Obras Casa do Bandeirante. Acervo PMSP/Pres.
No chão se fez a mesma investigação, removendo a terra batida (piso usual) dos lugares onde possivelmente, de acordo com a regra tipológica, poderiam estar escondidos alicerces de taipa (Figura 19). Os alicerces foram encontrados, e a parede foi reconstruída em tijolos.

A $2^{\text {a }}$. ETAPA foi dedicada ao desmonte e estudo do telhado: desmontou-se o madeiramento leve do telhado (ripas, retrancas, cachorros e forro de beiral) e se removeram as peças não originais (caibros roliços). Nesta etapa se examinaram os detalhes de carpintaria e o estado de conservação de cada peça. O exame do sistema construtivo total (telhado e paredes portantes) definiu o conceito da consolidação estrutural.

A casa do Butantã não apresentava, apesar dos numerosos pontos lacunosos na taipa e de fissuras em alguns pontos, desestabilização estrutural. A sua estabilidade estava preservada em decorrência da lógica do próprio sistema construtivo. As paredes principais, compostas por maciços independentes (somente encostados, sem amarração) formam dois anéis concêntricos. Entre os anéis, as paredes (também sem amarração) de divisão dos ambientes fazem o contraventamento dos maciços. As paredes de taipa são construídas sobre alicerces também de taipa. Além do peso próprio, as paredes suportam o peso do telhado, que é descarregado uniformemente ao longo da extensão das paredes com a ajuda de frechais pousados sobre o respaldo do anel externo e do anel interno (Figura 20). Os frechais (tanto no anel interno como no externo) trabalham tracionados pelos empuxos laterais dos caibros armados, anulando esses empuxos, de forma que os empuxos não são transmitidos às paredes. Às paredes são transmitidas exclusivamente cargas normais (forças verticais) (Figura 21). Cada anel formados pelos frechais mantém-se tracionado (e dessa forma anula os empuxos e cargas provenientes dos caibros) com a ajuda de sambladuras do tipo "rabo de andorinha" nas suas extremidades (Figura 22). 


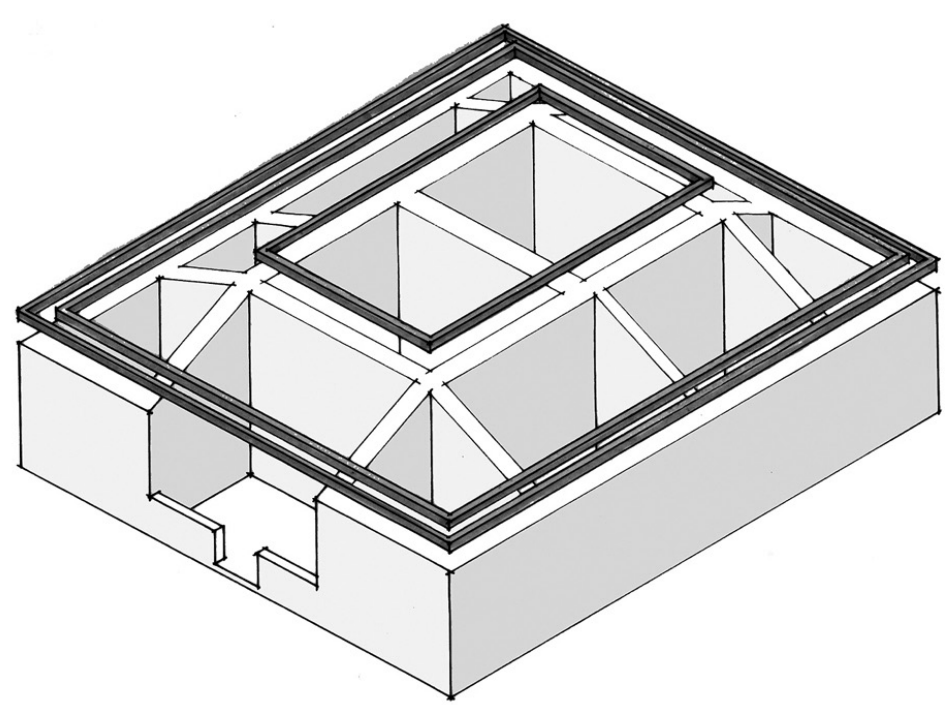

Figura 20 (topo): Desenho esquemático das paredes concêntricas com os frechais correndo sobre elas. Fonte: desenhos de Tatiana Cipoli, com base em croquis de Lia Mayumi.

Figura 21 (centro): Os frechais trabalham tracionados pelos empuxos laterais recebidos dos caibros armados. Fonte: Desenhos de Tatiana Cipoli, com base em croquis de Lia Mayumi.

Figura 22: Desenho esquemático das extremidades de cada frechal visto em planta, com sambladura do tipo rabo de andorinha.Fonte: desenhos de Tatiana Cipoli, com base em croquis de Lia Mayumi.
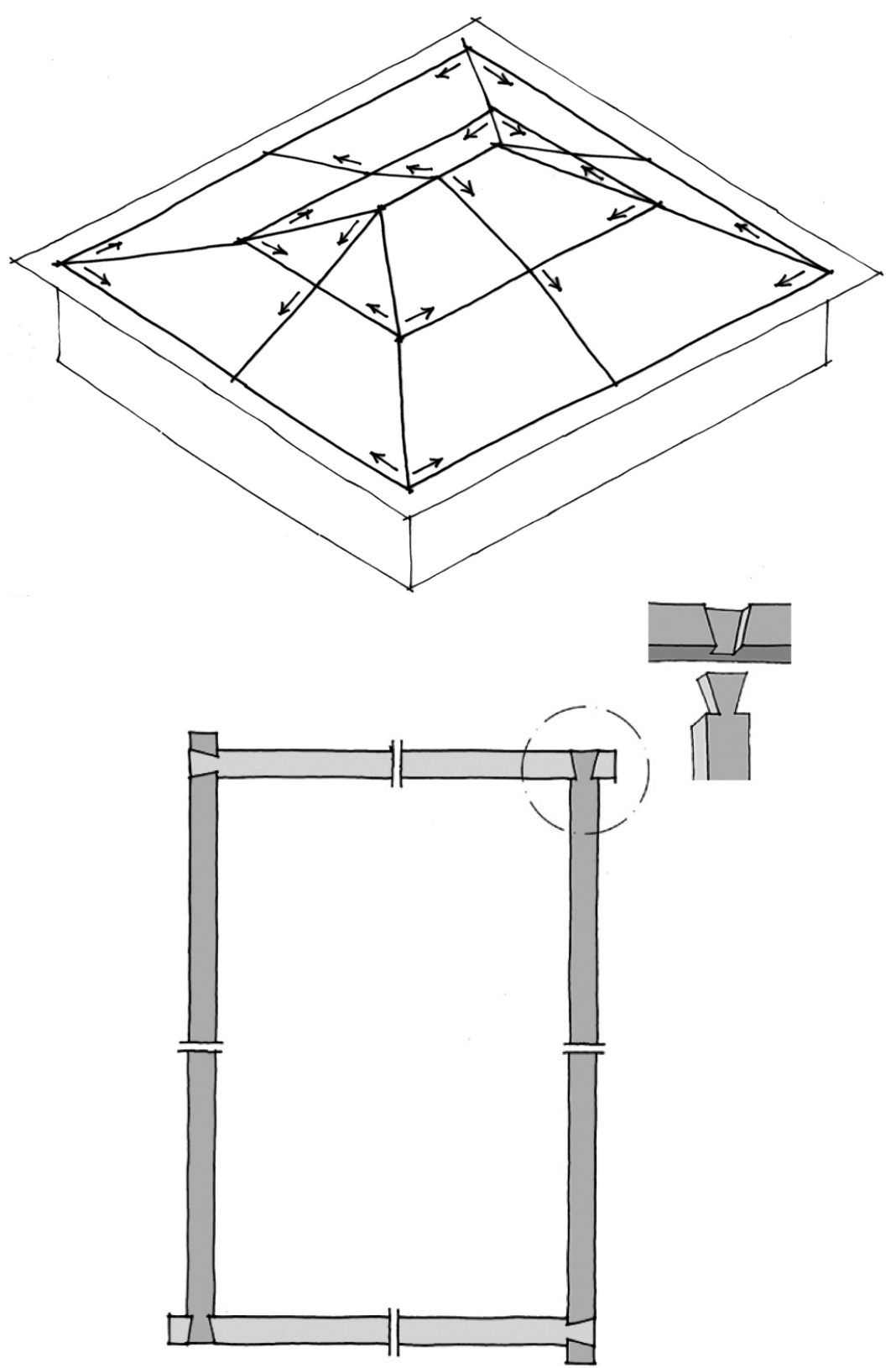
Figura 23 (esquerda): Respaldo da parede concêntrica interna, onde se vêem os caibros apoiados no fechal. Caibros e frechal semi-embebidos na taipa, antes da consolidação, em 5-8-1954.

Figura 24 (centro): Respaldo da parede concêntrica interna após a consolidação, onde se vê a cinta de concreto embebida, em 24-8-1954.

Figura 25 (direita): Parede concêntrica externa, com vala escavada na própria taipa, pronta para receber o concreto. Frechais e cachorros não foram removidos para a operação. Em 24-8-1954.

Fonte: fotografias de Germano Graeser, 1954, constante do "Caderno de Obras" da Casa do Bandeirante, acervo PMSP/DPH.
A $3^{a}$. ETAPA dessa obra correspondeu à consolidação estrutural. Como já foi visto, o edifício não apresentava problemas estruturais. A estrutura do telhado é originalmente projetada de forma que nenhum esforço lateral é transmitido às paredes. Apesar da falta de amarração e de sua separação, as paredes de taipa estavam perfeitamente aprumadas. Esse deve ser o quadro que levou à adoção de uma única medida de consolidação, qual seja, a introdução de uma cinta de concreto sobre o respaldo das paredes concêntricas. A cinta foi executada a partir da escavação de uma vala no respaldo das paredes concêntricas, de forma a ficar invisível e não alterar a altura do edifício. A vala tem a largura de um terço da espessura da parede.
Para a sua execução, os caibros, cachorros, e demais peças foram removidos na medida necessária, e depois recolocados. (Figuras 23 a 28)

As grandes lacunas formadas pela erosão da parte inferior das paredes externas foram preenchidas através do método tradicional do IPHAN, com placas de concreto moldadas no local. Pela face interna a própria parede funciona como forma. Pela face externa abre-se uma valeta de serviço, até alcançar o alicerce da parede, e depois se usam como formas tábuas escoradas por pontaletes (Figuras 5 e 6). As pequenas lacunas, constituídas por cabodás e trincas, foram fechadas com argamassa cimentícia (Figura 29).
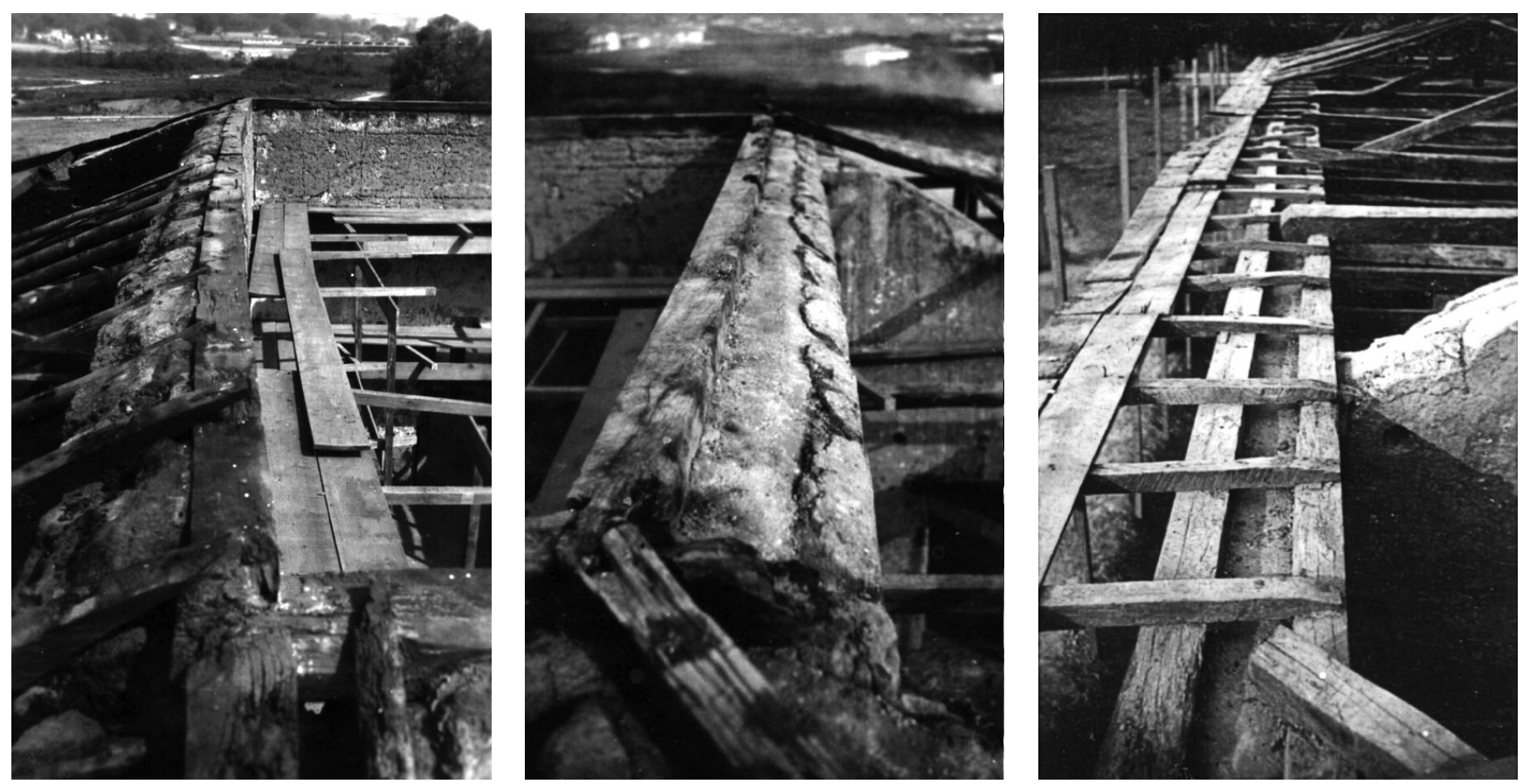

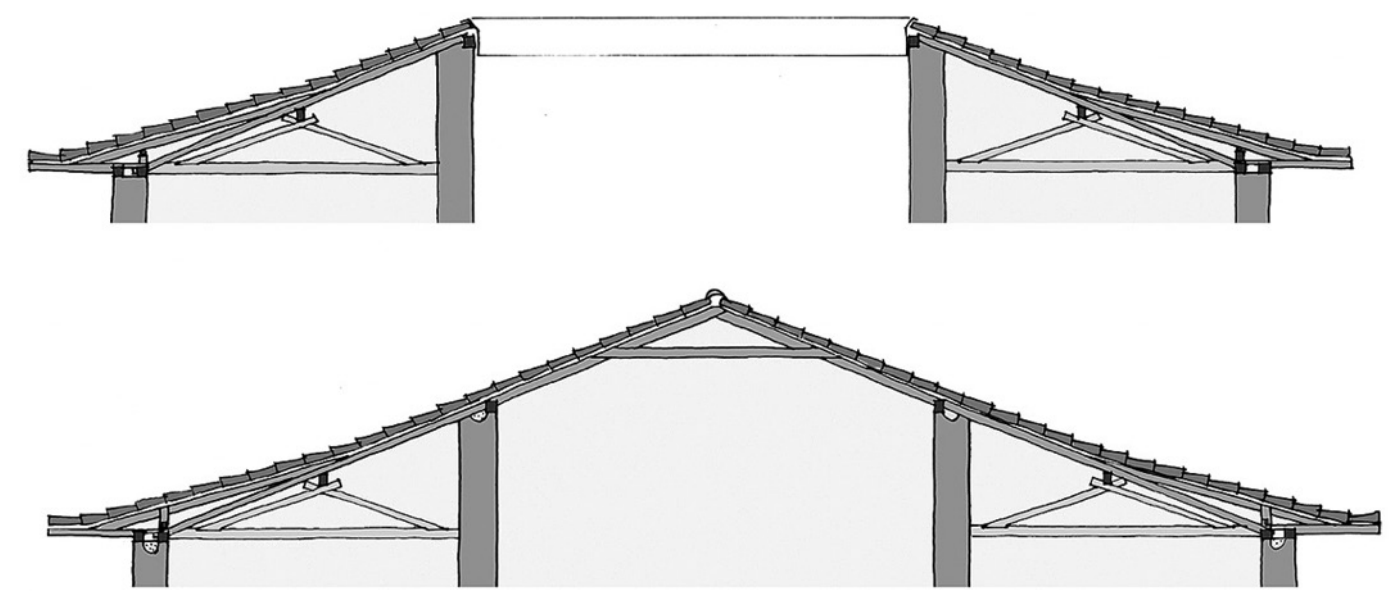

Figura 26 (topo): Corte transversal, mostrando esquema dos caibros armados antes e depois da restauração. Observe-se a parte do telhado que foi reconstituído sobre o vão central, antes e depois da restauração.

Figura 27 (centro): Detalhe do corte transversal, mostrando o local e dimensão da cinta de concreto no respaldo da parede concêntrica externa.

Figura 28: Detalhe do corte transversal, mostrando o local e dimensão da cinta no respaldo da parede concêntrica interna. $O$ desenho da esquerda mostra o rufo metálico encontrado antes da restauração, no local onde o frechal ficou descoberto pela ausência do telhado (Ver Figura 12).

Fonte: desenhos de Tatiana Cipoli, com base em croquis de Lia Mayumi.
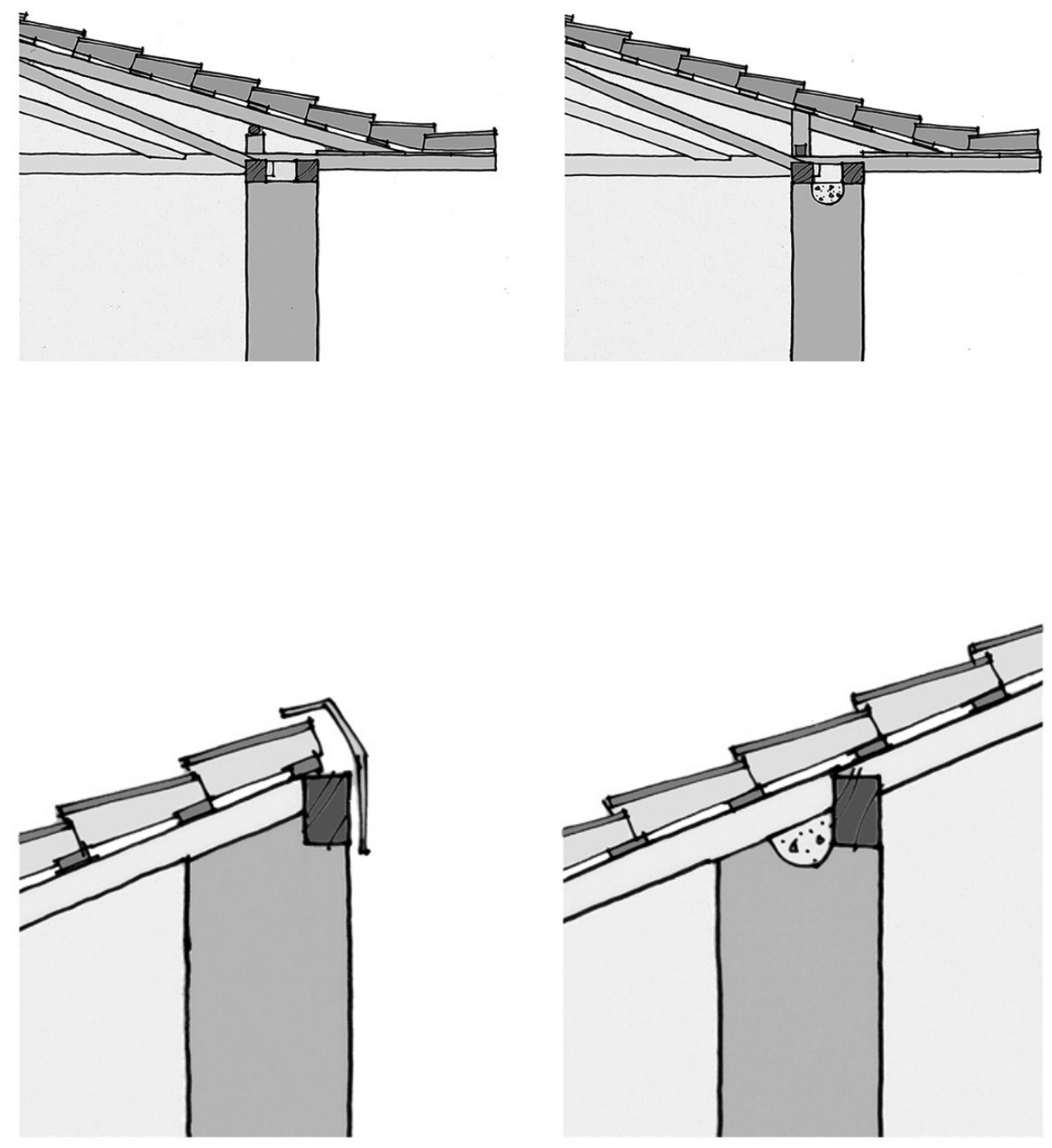


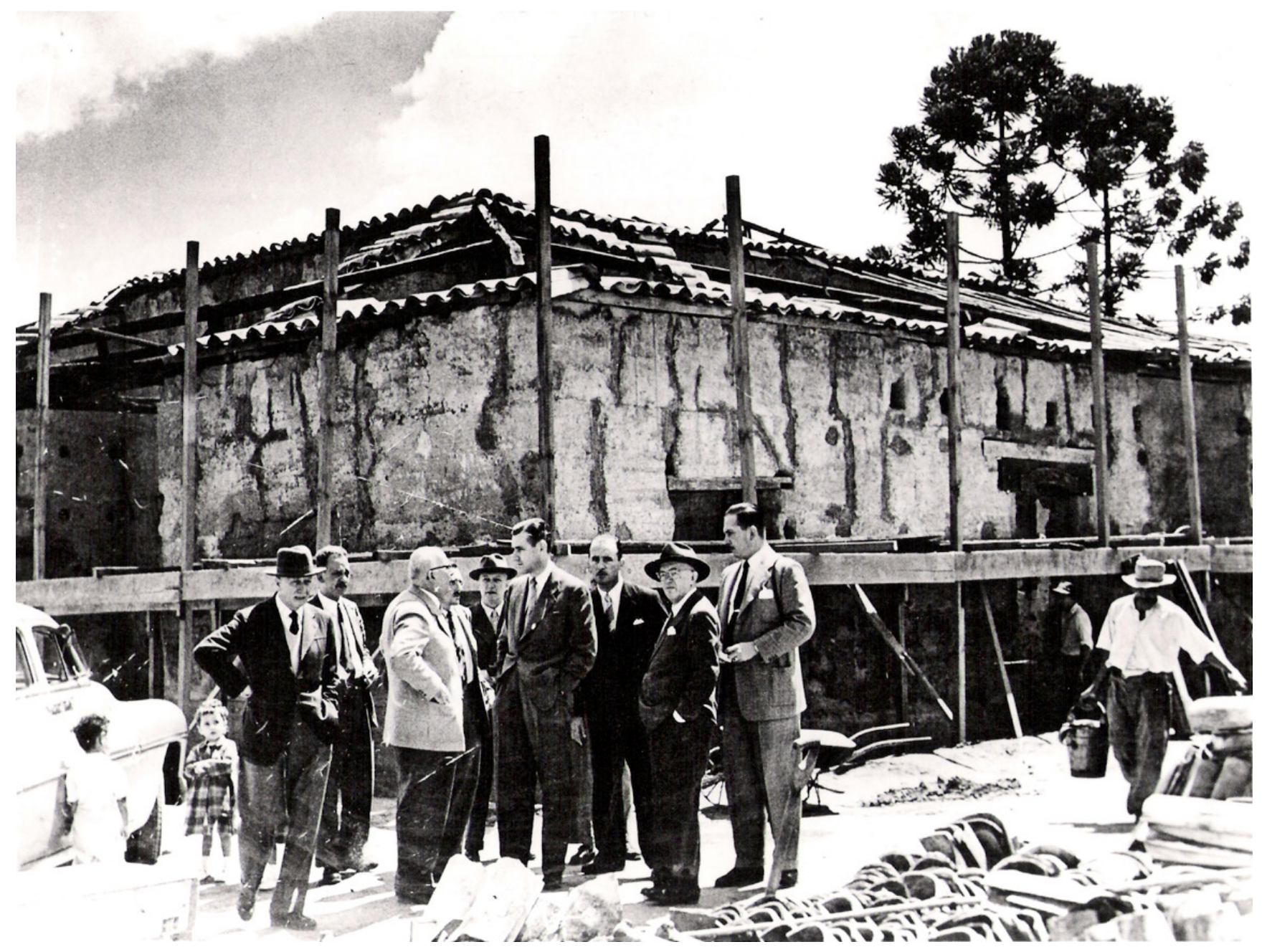

Figura 29: A Comissão do IV Centenário visita a obra, em 23-10-1954. No grupo principal, Luís Saia é o segundo da esquerda para a direita. O terceiro é Carlos Alberto Gomes Cardim Filho, conversando com Nilo Amaral, então Secretário de Obras da Prefeitura. Paulo Florençano, é o terceiro da direita para a esquerda. "Cáries" das paredes já obturadas. Ausência do esqueleto de concreto armado. Fonte: Acervo DPH/ Museu da Cidade. 
Figura 30: Teste de posicionamento das peças recuperadas do antigo telhado dobre o vão central, em 6-8-1954. Fonte: Caderno de Obras Casa do Bandeirante, Acervo PMSP/Pres.
A $4^{a}$. ETAPA da obra compreendeu a restauração de esquadrias das envasaduras, a reconstrução da parede do vão central, e serviços de acabamento (revestimento das paredes). Na cobertura, a restauração do telhado existente, e a construção da parte desaparecida sobre o vão central (Figuras 30 a 34). Em A Casa Bandeirista - uma interpretação(1955) Saia publicou a fotografia da Figura 30 explicando que foi possível reconstituir o desenho do telhado desaparecido porque algumas de suas peças foram encontradas em outras partes da edificação, trazidas para o local, reposicionadas, e usadas como modelo para a reconstrução.

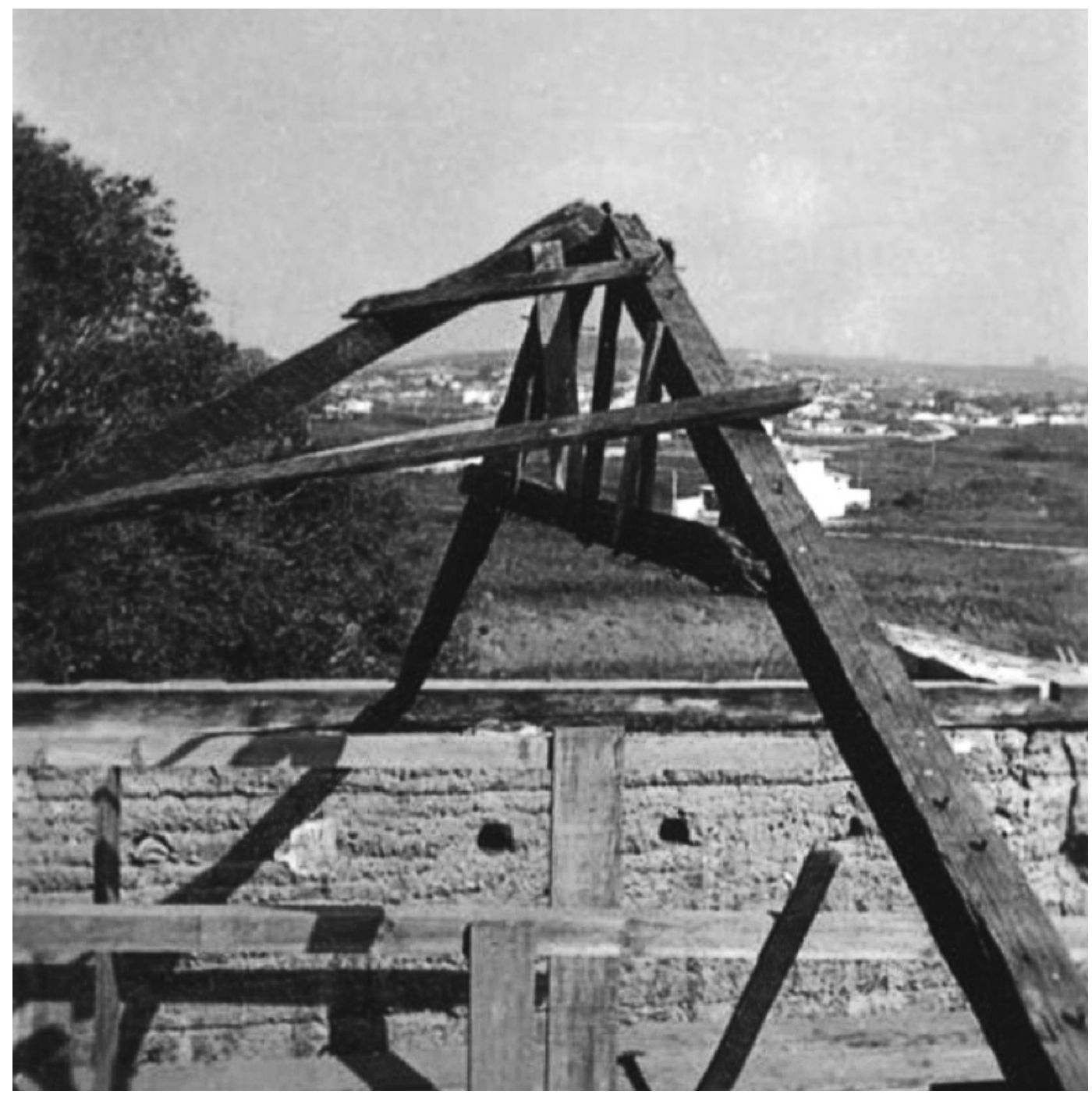



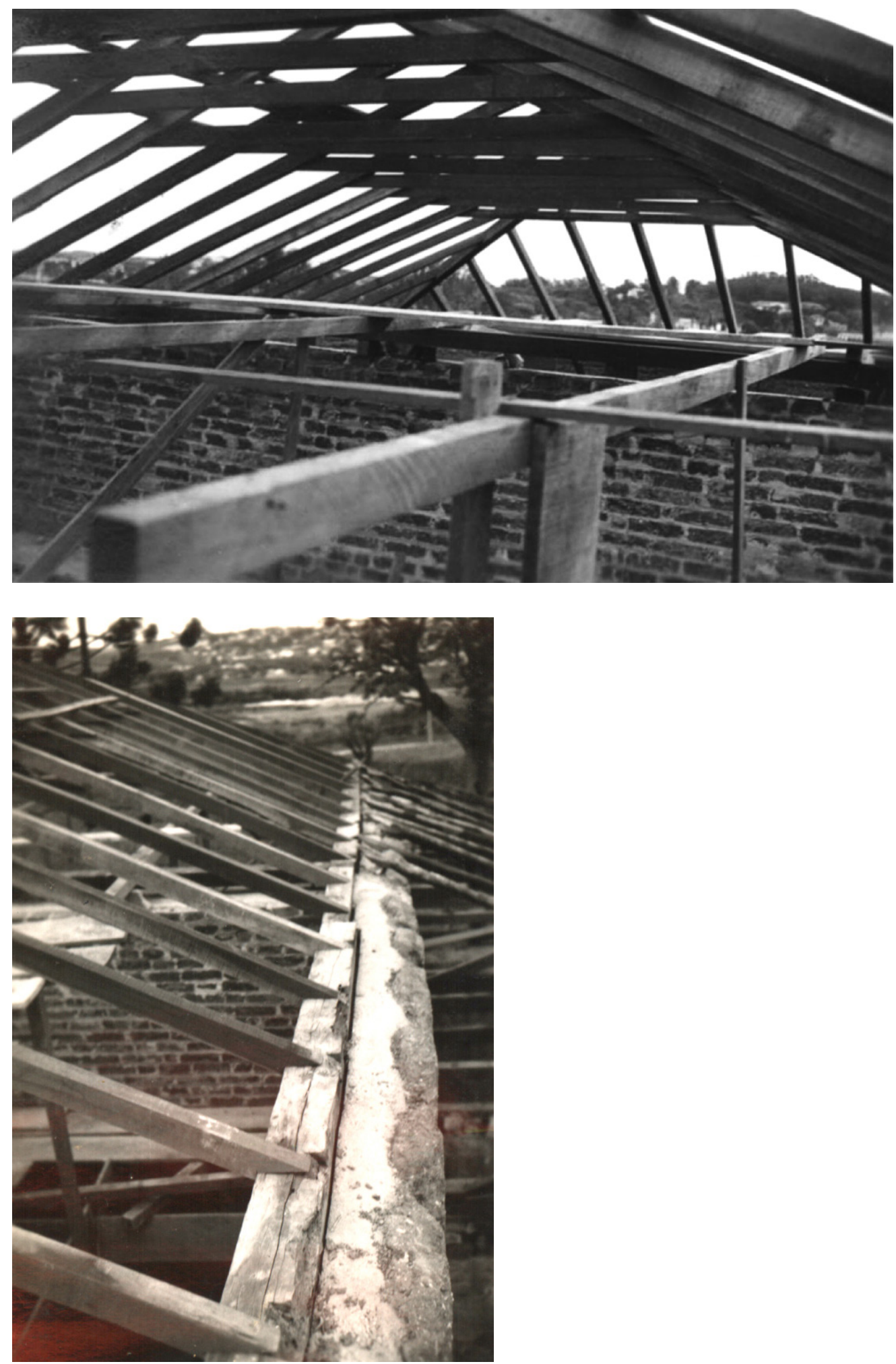

Figura 31 (topo): Telhado sobre o vão central já pronto, assim como parede reconstruída em tijolos, em 3-111954. Fonte: Caderno de Obras - Casa do Bandeirante, Acervo PMSP/Pres.

Figura 32: Asnas do telhado reconstruído, ancoradas no frechal da parede concêntrica interna, já com a cinta de concreto, em 3-11-1954. Fonte: Caderno de Obras Casa do Bandeirante, Acervo PMSP/Pres. 

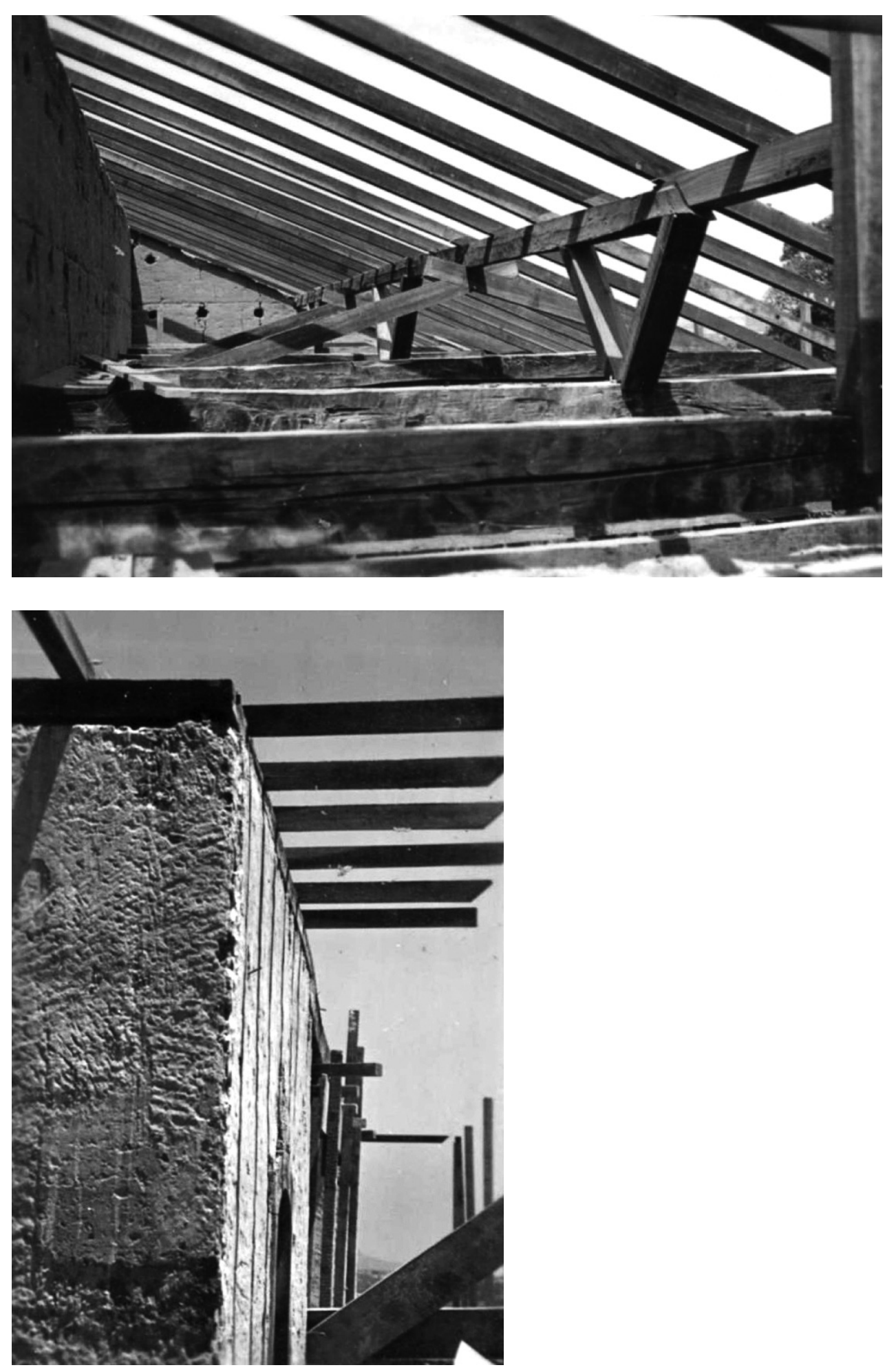

Figura 33 (topo): Madeiramento sobre o lanço Sul, restaurado, em 16-11-1954. Fonte: Caderno de Obras Casa do Bandeirante, Acervo PMSP/Pres.

Figura 34: Cunhal Sul - Leste, reboco grosso já aplicado, em 27-11-1954. Fonte: Caderno de Obras - Casa do Bandeirante, Acervo PMSP/ Pres. 
16 Encontramos registros de compra de 22 metros cúbicos de canela preta. Cf. Acervo IV Centenário, Processos $4.292 / 54,4.363 / 54 \mathrm{e}$ $5.574 / 54$

Figura 35 (topo) : Fachada Leste (principal) antes da restauração. Bases da parede erodidas.

Figura 36: Fachada Leste depois da restauração, sem argamassa de revestimento. Bases da parede "emplacadas", e "cáries" obturadas no alto. No alpendre, mureta nova de tijolos aproveitando o vestígio de taipa.

Fonte: desenhos de Tatiana Cipoli, com base em croquis de Lia Mayumi.
Portanto, a consolidação resumiu-se, na casa do Butantã, à introdução da cinta de concreto dentro do respaldo das duas paredes concêntricas. As Figuras 29 e 34 mostram com clareza que não foi adotado o recurso extremo da introdução do esqueleto de concreto armado.

A $5^{\mathrm{a}}$. ETAPA da obra correspondeu à conclusão do revestimento das paredes, com argamassa e pintura à base de cal. As madeiras, tanto do telhado como das esquadrias das envasaduras, não receberam cor, também conforme os procedimentos tradicionais do IPHAN.

A introdução de outros materiais além do concreto compreendeu essencialmente: a) a volumosa construção da parte nova do telhado, e a substituição de peças espúrias, por outras de canela preta ${ }^{16}$;

b) a aplicação de argamassa cimentícia na obturação de cáries (fechamento de lacunas, ver Figura 29) e no revestimento dos panos de alvenaria, assim como no assentamento de tijolos de paredes novas.

As intervenções estão exemplificadas nos desenhos a seguir, a fim de mostrar com mais clareza o caráter e a extensão de cada aspecto da intervenção (Figuras 35 a 40).
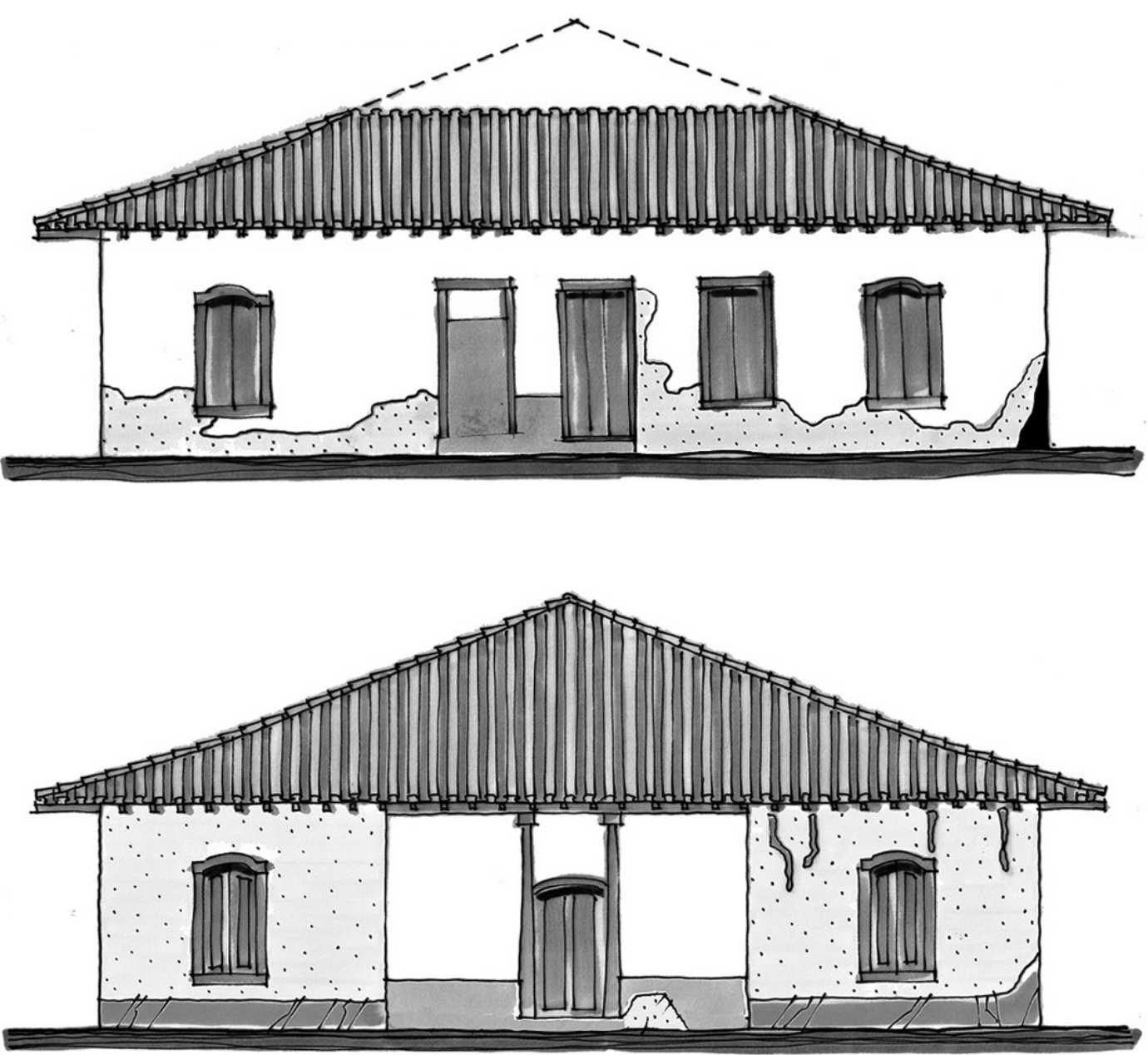

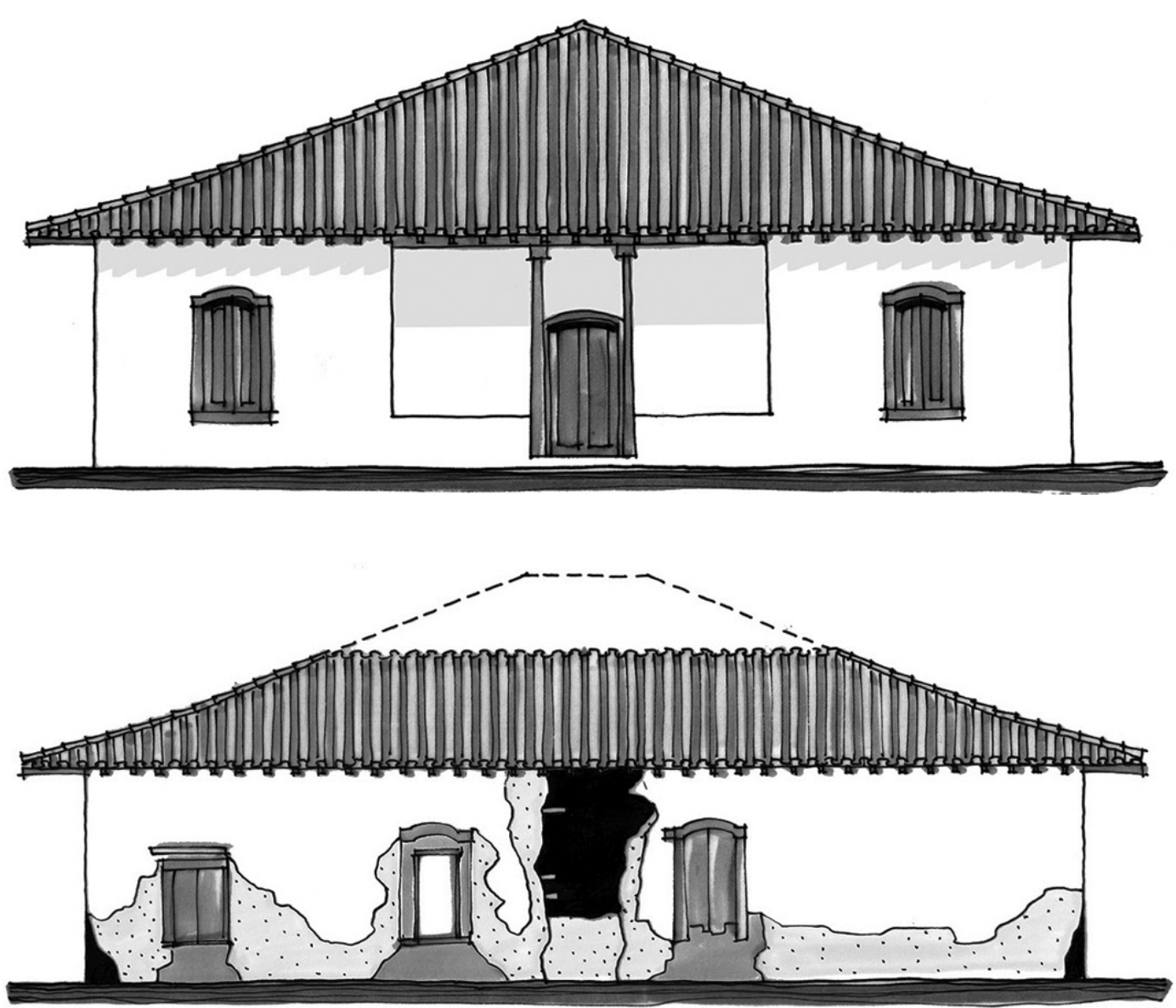

Figura 37 (topo): Fachada

Leste depois da restauração, revestida e caiada.

Figura 38: Fachada Sul (lanço esquerdo) antes da restauração, com buraco (ausência de material) na parede.

Figura 39: Fachada Sul depois da restauração, sem argamassa de revestimento. Buraco fechado com alvenaria de tijolos. Cáries obturadas.

Figura 40: Fachada Sul depois da restauração, revestida e caiada.

Fonte: desenhos de Tatiana Cipoli, com base em croquis de Lia Mayumi.
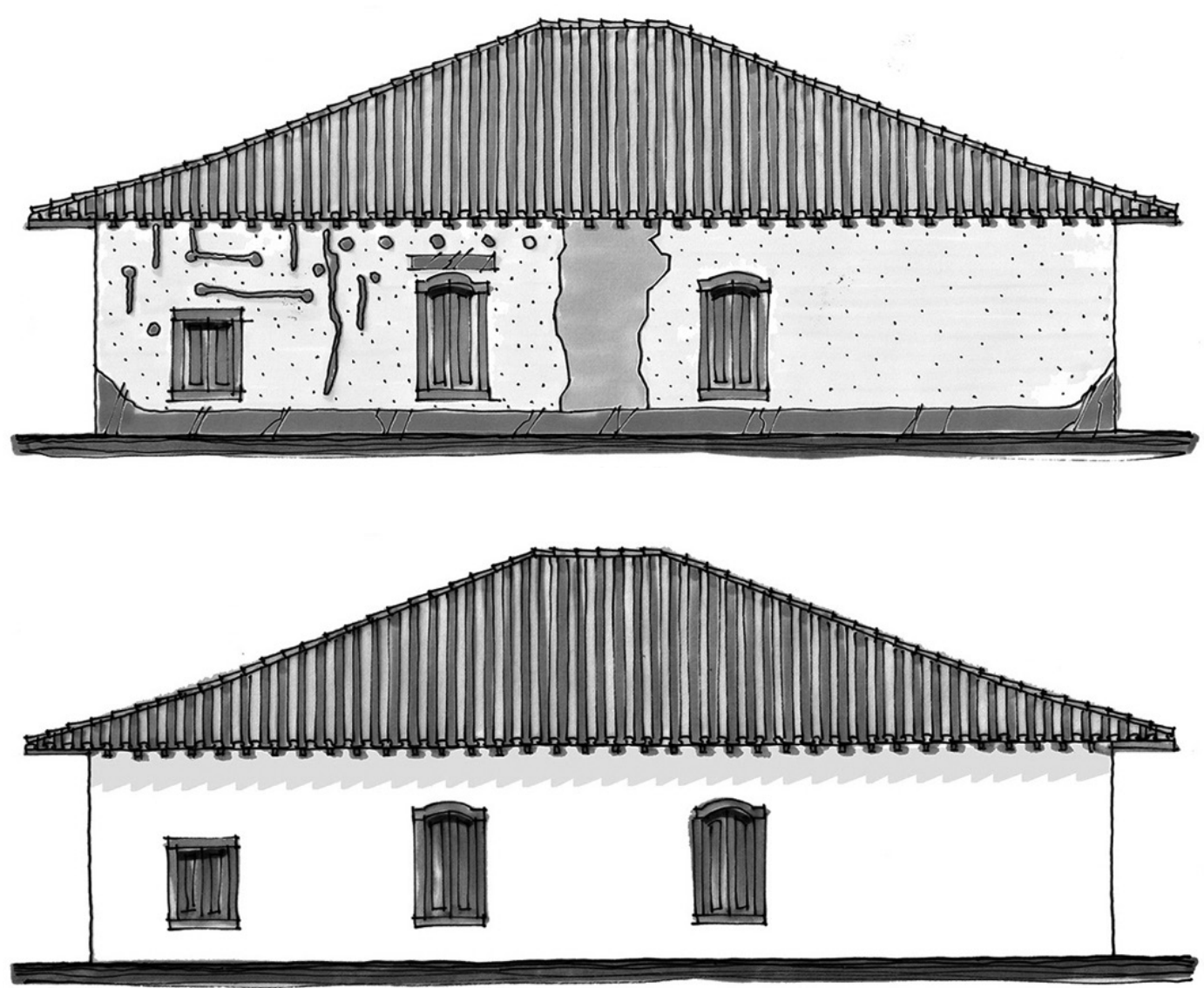


\section{O pioneirismo de saia}

As restaurações orientadas pela "tese original" estabelecida por Luís Saia em 1944 basearam-se na idéia de promover a remoção de qualquer traço de "decadência" do símbolo arquitetônico bandeirista, fosse ela decadência material ou simbólica. A intenção de dignificação das "casas velhas" foi explicitada por Saia nos seus textos, seja na busca de uma justificativa genético-tipológica nobre Palladio -, seja na construção de uma idéia de entrelaçamento entre o tipo arquitetônico e a psicologia do fazendeiro bandeirante.

Através das restaurações, Saia conseguiu efetivar a dignificação desejada para as casas. Daí, a grande importância do exame e da análise detalhada dos processos envolvidos em cada uma das obras de restauração. O exame de cada obra de restauração dirigida por Saia revela o comprometimento deste com as teses estabelecidas nos seus escritos. A começar pela supressão dos traços da construção que Saia considerava estarem em desacordo com o esquema bandeirista, e terminando com a reinserção da casa num contexto urbano do século XX considerado digno, o que incluía aplicar rebocos impecavelmente regulares e pintura alvíssima sobre as fachadas, além de criação de uma paisagem no entorno da casa que a emoldurasse organizadamente e acentuasse o seu protagonismo. Nesse esquema de organização da paisagem, tanto quanto na obra de restauração propriamente, embutiam-se os ideais modernistas nem sempre explicitados por Saio nos textos, mas dos quais ele certamente estava imbuído. O emprego do concreto armado nas restaurações, além de representar um experimento de vanguarda dos arquitetos do IPHAN Brasil afora, significou a convicção destes, Saia inclusive, na eficácia do convívio dessa técnica nova com os monumentos antigos, refletindo assim o compromisso dos modernistas do IPHAN com a visão de monumento do Modernismo propagado nos CIAM (1933) e na Carta de Atenas de restauro (1931).

Reside o mérito de Saia, referente às casas bandeiristas, no pioneirismo com que conseguiu construir um discurso histórico, ideológico e técnico sobre essas casas, operando efetivamente sobre a materialidade das casas através das obras de restauração, e inserindo-as no universo de bens arquitetônicos reconhecidos como patrimônio his- tórico. As restaurações, por sua vez, estabeleceram os primeiros critérios de intervenção em casas bandeiristas, inaugurando o caminho trilhado posteriormente por outros arquitetos.

\section{Referências bibliográficas}

AMARAL, Aracy. A Hispanidade em São Paulo. São Paulo: Nobel: EDUSP, 1981

ANDRADE, Antonio Luiz Dias de. Um estado completo que pode jamais ter existido. São Paulo: Tese de Doutoramento apresentada à FAU-USP em 1993.

ANDRADE, Rodrigo Mello Franco de. "Patrimônio Histórico e Artístico Nacional". In: Revista do Instituto Hlistórico e Geográfico Guarujá/ Bertioga n 12 . São Paulo, 1981.

BRUNO, Ernani Silva. O Equipamento da Casa Bandeirista Segundo os Antigos Inventários e Testamentos. São Paulo: Departamento do Patrimônio Histórico, 1977.

GONÇALVES, Cristiane Souza. Metodologia para a Restauração Arquitetônica: A experiência do Serviço do Patrimônio Histórico e Artístico Nacional em São Paulo, 1937-1975. São Paulo, Dissertação de Mestrado apresentada à FAUUSP, 2004.

KATINSKY, Julio Roberto. Casas Bandeiristas. Nascimento e reconhecimento da arte em São Paulo. São Paulo: IGEOG-USP, 1976. Série Teses e Monografias n 26. Tese apresentada à FAU-USP em 1972.

LEAL, Fernando Machado. Restauração e Conservação de Monumentos Brasileiros. Recife: UFPE, 1977.

LEMOS, Carlos Alberto Cerqueira. "À procura da memória nacional". In: DPH ELETROPAULO n. 17. São Paulo: DPH ELETROPAULO, jan. fev. mar 1993. PP. 17 - 24

Casa Paulista. História das moradias anteriores ao ecletismo trazido pelo café. São Paulo: EDUSP, 1999.

MAYUMI, L. Taipa, canela preta e concreto. São Paulo: Romano Guerra, 2008.

MONTALVO, Antônio José Aguilera. Fenomenologia e a "teoria da restauração": a fundamentação da teoria de Cesare Brandi. Rio de Janeiro: dissertação de mestrado apresentada a Faculdade de Arquitetura e Urbanismo da UFRJ, 1998.

MORI, Victor Hugo, LEMOS, Carlos A C, CASTRO, Adler $\mathrm{H}$ Fonseca de. Arquitetura Militar. Um panorama histórico a partir do porto de Santos. São Paulo: Imprensa Oficial do Estado: Fundação Cultural Exército Brasileiro, 2003.

PRADO, Paulo. Paulística. História de São Paulo. Rio de Janeiro: Ariel, 1934. $2^{\circ}$ ed

SAIA, Luiz. "A Casa Bandeirista (uma interpretação)" São Paulo: Comissão do IV Centenário da Cidade de São Paulo, 1955.

"Notas sobre a arquitetura rural paulista do segundo século". In: Revista do SPHAN n. 8. Rio de Janeiro, 1944. pp. 211-275. 